\title{
A VÁLLALATI KORMÁNYZÁS GYAKORLATA A MAGYARORSZÁGI GYÓGYSZERIPARI TÁRSASÁGOKNÁL
}

A szerzố dolgozatában a magyarországi gyógyszeripari cégek vállalati kormányzási gyakorlatát vizsgálta egy németországi kérdốiv segítségével végzett felmérés alapján. A felmérés a vállalatok tulajdonosi szerkezetét, a menedzsment és a vezető testületek (igazgatóság és felügyelóbizottság) összetételét, múködését, szerepét és a társaság múködtetésére gyakorolt hatását vizsgálta. Emellett a kérdőív egy külön fejezetben kitért a vállalati múködés egyéb érintetteinek befolyására is. A felmérés eredményeinek összegzéseként összegyújjtötte azokat a jellemzóket, amelyek a kapott válaszok tanúsága szerint általában igazak a magyarországi gyógyszeripari társaságok kormányzási gyakorlatára.

Kulcsszavak: vállalati kormányzás, corporate governance, gyógyszeripar

A vállalati kormányzás (corporate governance) a vezetéstudomány viszonylag új területe, amely az utóbbi években egyre inkább az érdeklődés középpontjába került. A témával foglalkozó tanulmányok száma megsokszorozódott az elmúlt másfél évtizedben, és számos ajánlás is született a vállalatok kormányzási gyakorlatára vonatkozóan.

A magyarországi vállalatok kormányzási gyakorlatával eddig kevés kutatás foglalkozott. Ráadásul a kormányzást befolyásoló tényezốk jelentôs változásokon mentek keresztül a rendszerváltozás óta, így valószínúsíthetô, hogy a társaságirányítási gyakorlat is sokat változott ez idô alatt. A privatizáció, a tulajdonosi struktúra átalakulása, a piacok megnyitása, új vezetési megoldások elterjedése, újszerú vállalati kultúrák kialakulása, a szabályozási környezet változásai, a német és az angolszász befolyás erősödése mind ezt a feltételezést támasztják alá. És a változások még napjainkban is folytatódnak, hiszen a Budapesti Értéktôzsde csupán három éve fogalmazta meg Felelős Vállalatirányítási Ajánlásait, és a gazdasági társaságokról szóló új törvény, amely alapvetóen befolyásolja a vállalati kormányzás gyakorlatát, 2006. július 1-jén lépett életbe.

Mindezek miatt a vállalati kormányzás magyar gyakorlatának kutatása nagyon aktuális és szükségszerú. Ezzel a dolgozattal ehhez a kutatáshoz szeretnék hozzájárulni. Ugyanakkor az általam végzett felmérés a magyar gazdaságnak csupán egy szúk szeletével, a gyógyszeriparral foglalkozik, s azon belül is csak néhány vállalatot érint. Ennek az is az oka, hogy a témából adódóan leginkább a részvénytársaságok kormányzási módszerei relevánsak a kutatás szempontjából, s ez a társasági forma Magyarországon - nem csak a gyógyszeriparban - sokkal kevésbé elterjedt, mint más formák. Azért a gyógyszeriparra esett a választásom, mert ennek az iparágnak nagy hagyományai vannak hazánkban, és ebben a szektorban több nagyméretú és sikeres társaság is tevékenykedik. Ennek megfelelôen dolgozatom középpontjában a magyarországi gyógyszeripari társaságok kormányzási módszereinek vizsgálata áll.

A felmérés eredményeinek ismertetésén túl megpróbálom összegezni a vállalatokra általában jellemzó módszereket és megoldásokat, és megtalálni a felmérés során tapasztalt eltérések magyarázatát. Mindezek alapján dolgozatom végén megkísérlem összefoglalni azokat a tényezóket, amelyek leginkább befolyásolják egy vállalat kormányzási gyakorlatát.

\section{Vállalati kormányzás}

A vállalati kormányzás (corporate governance) igen tág fogalom, mely számos gazdasági jelenséget 
érint. Ennek megfelelóen az elmúlt években sok, egyes esetekben egymástól jelentôsen eltérô definíció született a témában. ${ }^{1}$ A különbségek többnyire abból adódnak, hogy az egyes meghatározások más és más oldalról közelítik meg a kérdést, azaz a társaságirányítás különböző aspektusait hangsúlyozzák. A késóbbiekben bemutatott kutatás logikájának megfelelően a vállalati kormányzás fogalmát a következóképpen értelmezem:

A vállalati kormányzás a gazdasági társaságok olyan irányítási mechanizmusa, ahol a döntési jogkörök, a hatalom és a felelósség - meghatározott szabályok szerint - megoszlik egyrészt a kormányzó testületek között, másrészt a testületeken belül a testületi tagok közt; s amely mechanizmust - a kormányzó testületeken és tagjaikon kivül - egyéb érintettek (stakeholder) is befolyásolhatnak.

A definíció nem szúkíti le explicit módon a gazdasági társaságok vizsgálandó körét. Ennek oka az, hogy nem lehet élesen elhatárolni egymástól egyéb jellemzóik alapján a kormányzási eszközöket és módszereket alkalmazó és nem alkalmazó vállalatokat. A mechanizmus komplexitása miatt azonban azt mondhatjuk, hogy minél nagyobb és összetettebb egy vállalat, minél bonyolultabb a tulajdonosi struktúrája, minél nagyobb gazdasági súllyal rendelkezik stb., annál inkább indokolt és szükségszerú a társaságirányítási eszközök és módszerek alkalmazása. A magyar törvényi szabályozást tekintve leginkább a korlátolt felelôsségú társaságok (kft.) és a - zártkörúen vagy nyilvánosan múködô - részvénytársaságok (rt.) vezetésére igazak a corporate governance jellemzói. Kutatásom ezeken belül is a valószínúleg legösszetettebb társaságirányítási rendszerrel rendelkező részvénytársaságok egy csoportjára koncentrál.

A fenti meghatározásnak megfelelően kutatásomban - a felhasznált kérdőív struktúráját követve - elsődlegesen a vállalat (konkrétan a részvénytársaság) irányításához szorosan kötôdó aktorok - a tulajdonosok (közgyúlés), a tulajdonosok megbízottjai (igazgatóság és felügyelőbizottság), valamint a vállalati felsővezetốk (menedzsment) - szerepét vizsgálom. Az egyéb érintettek (a munkavállalók, a vásárlók, a beszállítók, a bankok, az állam, a társadalom stb.) hatását kevésbé hangsúlyosan tárgyalom.

\section{A vállalati kormányzás gyakorlata a magyarországi gyógyszeripari társaságoknál}

$\mathrm{Az}$ alábbiakban tehát egy kérdő́ives felmérés eredményeit mutatom be, amelyet a magyarországi, részvénytársasági formában múködő gyógyszeripari cégek körében végeztem. Az eredmények ismertetése mellett kitérek a kutatás hátterére, a vizsgált vállalatok kiválasztásának szempontjaira is, de mindezek elótt a magyar gyógyszeripar rövid bemutatása következik.

\section{A magyar gyógyszeripar számokban}

A hazai gyógyszerpiac 2005-ös forgalma termelői áron 457,1 milliárd forintot tett ki. A piac termelôi áron számított forgalma az elmúlt években dinamikusan

\section{1. ábra}

A magyar gyógyszerpiac fejlódése

az eladott dobozok száma és a termelôi áron számított forgalom szerint ${ }^{2}$

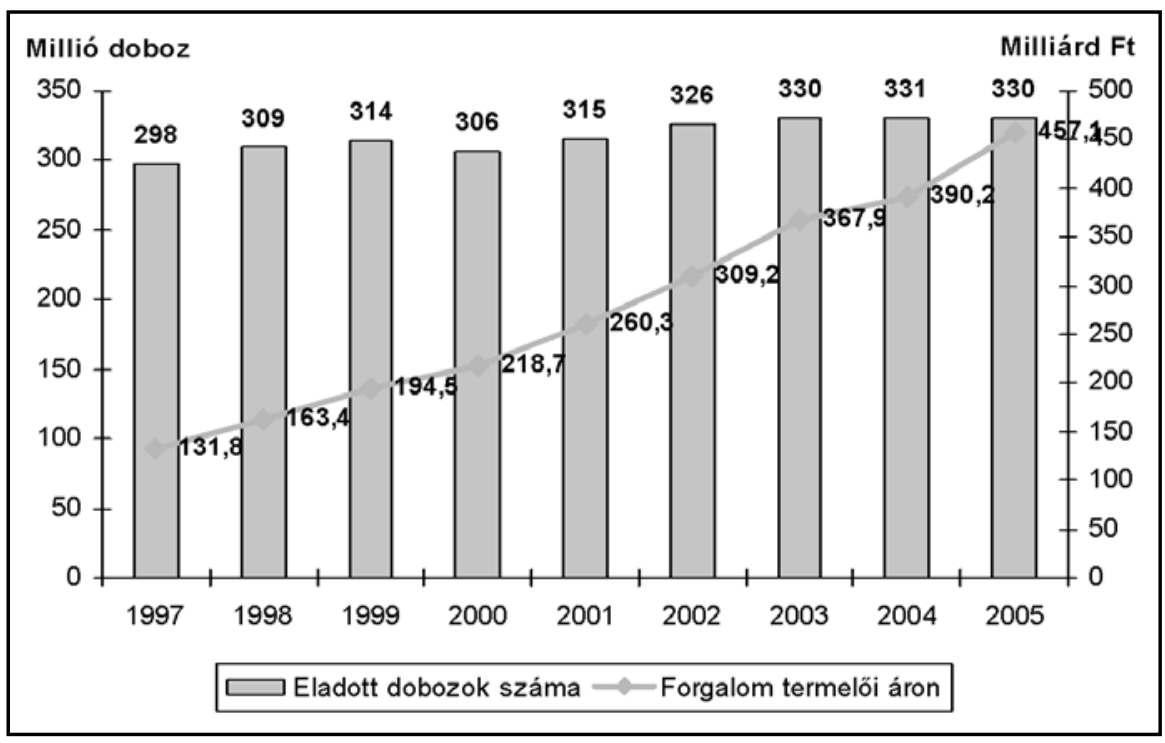

nôtt, míg az eladott dobozok száma alig változott. Termelôi áron számítva a forgalom közel 84\%-át gyógyszertárakban realizálták, míg a fennmaradó 16\% kórházi felhasználásra került (1. ábra).

A hazai piac elsố húsz szereplője közt valamennyi nagy magyar gyógyszergyártó megtalálható, és az első húsz termék közül is többet Magyarországon gyártanak. Néhány évvel ezelőtt még a Richter Gedeon és az Egis rendelkeztek a legnagyobb piaci részesedéssel, de az utóbbi egy-két évben megváltozott a vezetô vállalatok sorrendje. Ebben szerepet játszott az is, hogy még az elmúlt években is történtek jelentôs változások az egyes vállalatok tulajdonosi szerkezetében. Az egyik ilyen fontos változás, hogy a Sanofi, amely 1997-tôl a Chinoin részvényeinek több mint $99 \%$-át birtokol- 
ja, 1999-ben összeolvadt a Synthélabóval, s a francia vállalatcsoport 2001-ben Magyarországon létrehozta a Sanofi-Synthélabo Rt.-t. A Sanofi-Synthélabo 2005ben fuzionált az Aventisszel, s így francia központtal megszületett az Európában elsô, a világon harmadik legnagyobb gyógyszeripari csoport ${ }^{3}$. Így Magyarországon is a sanofi-aventis (Chinoin) vette át a piacvezető szerepet. Szintén jelentôs változás, hogy az izraeli TEVA, amely a '90-es évek második felében 99\% feletti részesedést szerzett a debreceni Biogal gyógyszergyárban, 2000-ben a HUMAN tulajdonosa is lett. A vállalatok 2005. január elseje óta TEVA közös családnév alatt múködnek ${ }^{4}$. Vannak olyan vállalatok is, amelyek sorsa valószínúleg még mindig nem dólt el véglegesen. A Tiszavasváriban múködó ICN Magyarország Rt.-t (korábbi Alkaloida) 2005-ben az indiai Sun Pharmaceutical Industries Ltd vásárolta meg a Valeant Pharmaceuticals International-től (korábbi ICN Pharmaceuticals) ${ }^{5}$. A 90-es években nagy sikereket elért Pharmavit sorsa - amely késóbb a Bristol-Myers Squibb tulajdonába került - szintén kérdéses.

Ezeknek az átalakulásoknak és a piaci változásoknak köszönhetően tehát a piacvezető vállalatok sorrendje az utóbbi években is változott. Különböző sorrendet kaphatunk aszerint is, hogy a forgalmat vagy az eladott dobozok számát vesszük figyelembe. Az utóbbi osztályozás a magyar vállalatoknak kedvez. Az 1. táblázat a 2005-ös termelôi áron számított forgalom alapján rangsorolja a társaságokat (2. táblázat).

A hazai gyógyszerpiac vezetố vállalatai 2005-ben ${ }^{6}$

\begin{tabular}{|l|c|c|}
\hline Piacvezetó vállalatok & $\begin{array}{c}\text { Forgalom } \\
\text { termelói } \\
\text { áron } \\
\text { (millió Ft) }\end{array}$ & $\begin{array}{c}\text { Piaci } \\
\text { részesedés } \\
(\%)\end{array}$ \\
\hline Teljes piac & 457156 & 100,00 \\
\hline 1. SANOFI-AVENTIS & 45481 & 9,95 \\
\hline 2. NOVARTIS & 36955 & 8,08 \\
\hline 3. RICHTER GEDEON & 34754 & 7,60 \\
\hline 4. EGIS & 30087 & 6,58 \\
\hline 5. PFIZER & 29212 & 6,39 \\
\hline 6. TEVA & 25951 & 5,68 \\
\hline 7. ROCHE & 20166 & 4,41 \\
\hline 8. ASTRAZENECA & 19461 & 4,26 \\
\hline 9. GLAXOSMITHKLINE & 17945 & 3,93 \\
\hline 10. MERCK SHARP DOHME & 16563 & 3,62 \\
\hline
\end{tabular}

2005-ben a vény nélkül kapható (OTC - over-thecounter) gyógyszerek termelói áron számított forgalma a teljes piac 12,8\%-át tette ki (52 milliárd Ft). Ez az arány az elmúlt években viszonylag stabilnak mondható. Ugyanakkor a vény nélkül kapható gyógyszerek száma jelentősen nőtt a rendszerváltozást követôen. Míg 1990-ben 134 gyógyszert lehetett kapni vény nélkül (az összes forgalmazott gyógyszer 11\%-a), addig 2000-ben már 764 OTC-termék volt forgalomban (az összes forgalmazott gyógyszer $18,5 \%$-a $)^{7}$. A vezetô OTC-termékek 2005-ben: az Algopyrin ${ }^{8}$ (gyártó: sanofi-aventis), a Béres Csepp (Béres), a Neo Citran (Novartis), az Aspirin (Bayer) és az Astrix (TEVA) A vezetô gyógyszeripari vállalatok többnyire az OTC ${ }^{9}$-piacon is jelen vannak, de olyan társaság is van, amely kifejezetten erre a piacra specializálódott. 2005-ben az $\mathrm{OTC}^{10}$-piac tíz vezető vállalata a 2 . táblázatban látható.

2. táblázat

A magyar OTC piac vezetố vállalatai, 2005

\begin{tabular}{|l|c|}
\hline \multicolumn{1}{|c|}{ Vállalat } & $\begin{array}{c}\text { OTC } \\
\text { piaci részesedés } \\
(\boldsymbol{\%})\end{array}$ \\
\hline 1. SANOFI-AVENTIS & 18,2 \\
\hline 2. NOVARTIS & 10,1 \\
\hline 3. BAYER & 9,5 \\
\hline 4. TEVA & 7,9 \\
\hline 5. EGIS & 4,4 \\
\hline 6. BÉRES & 4,2 \\
\hline 7. GLAXOSMITHKLINE & 3,5 \\
\hline 8. BERLIN-CH/MENARINI & 3,5 \\
\hline 9. RICHTER GEDEON & 3,4 \\
\hline 10. WYETH & 2,4 \\
\hline
\end{tabular}

A hazai értékesítés mellett több magyarországi gyógyszergyár folytat exporttevékenységet is. Ennek megfelelóen ismét egy eltérô rangsort kapunk, ha a vállalatok teljes tevékenységének eredményét vizsgáljuk. A 3. táblázat Magyarország legnagyobb 200 vállalata közt szereplő gyógyszeripari cégek néhány adatát tartalmazza (3. táblázat).

\section{A kutatás háttere}

Kutatásom során Magyarországon múködő gyógyszeripari cégek vállalati kormányzási gyakorlatát vizsgáltam. A felmérésre 2006 márciusában és áprilisában került sor egy kérdőív segítségével.

\section{A kérdö́iv}

A felmérés során használt kérdôív a németországi Chemnitz-i Egyetem angol nyelvú kérdőívén alapul. Az eredeti kérdőívet Angyal Ádám és Csanda Júlia a magyarországi körülményeknek megfelelően egy pon- 
3. táblázat

Magyarország legnagyobb 200 vállalata közt szereplő gyógyszeripari cégek

néhány fontos adata 2004-re vonatkozóan

\begin{tabular}{|c|c|c|c|}
\hline $\begin{array}{l}\text { Rang- } \\
\text { sor }\end{array}$ & Társaság neve & $\begin{array}{l}\text { Értékesí- } \\
\text { tés nettó } \\
\text { árbevétele } \\
\text { (millió Ft) }\end{array}$ & $\begin{array}{l}\text { Export- } \\
\text { értékesítés } \\
\text { (millió Ft) }\end{array}$ \\
\hline 40. & $\begin{array}{l}\text { Richter Gedeon Vegyészeti } \\
\text { Gyár Rt. }\end{array}$ & 121593 & 85944 \\
\hline 48. & $\begin{array}{l}\text { Chinoin Gyógyszer és Ve- } \\
\text { gyészeti Termékek Gyára Rt. }\end{array}$ & 90797 & 64566 \\
\hline 50. & TEVA Gyógyszergyár Rt. & 86029 & 72779 \\
\hline 67. & Egis Gyógyszergyár Rt. & 66108 & 39117 \\
\hline 148. & Novartis Hungária Kft. & 30003 & 377 \\
\hline 165. & Roche Magyarország Kft. & 27127 & 4095 \\
\hline 185. & $\begin{array}{l}\text { Pfizer } \\
\text { Gyógyszerkereskedelmi Kft. }\end{array}$ & 24537 & - \\
\hline 189. & GlaxoSmithKline Kft. & 24333 & 5684 \\
\hline $\begin{array}{l}\text { Rang- } \\
\text { sor }\end{array}$ & Társaság neve & \begin{tabular}{|c|} 
Átlagos \\
statisztikai \\
létszám \\
(fó)
\end{tabular} & Saját tốke \\
\hline 40. & $\begin{array}{l}\text { Richter Gedeon Vegyészeti } \\
\text { Gyár Rt. }\end{array}$ & 5542 & 198943 \\
\hline 48. & $\begin{array}{l}\text { Chinoin Gyógyszer és Ve- } \\
\text { gyészeti Termékek Gyára Rt. }\end{array}$ & 2046 & 75582 \\
\hline 50. & TEVA Gyógyszergyár Rt. & 1177 & 152347 \\
\hline 67. & Egis Gyógyszergyár Rt. & 2754 & 73891 \\
\hline 148. & Novartis Hungária Kft. & 215 & 1553 \\
\hline 165. & Roche Magyarország Kft. & 142 & 2406 \\
\hline 185. & $\begin{array}{l}\text { Pfizer } \\
\text { Gyógyszerkereskedelmi Kft. }\end{array}$ & 287 & 1938 \\
\hline 189. & GlaxoSmithKline Kft. & 235 & 7588 \\
\hline
\end{tabular}

ton módosították, ugyanis abban vezető testületként csak a felügyelóbizottság szerepelt, ezért pótlólag felvették az igazgatóságot ugyanazokkal a kérdésekkel, amelyek az eredeti kérdőívben a felügyelóbizottságra vonatkoztak ${ }^{11}$. A német és a magyar törvényi szabályozás és kormányzási rendszer közti különbségeknek köszönhetôen, és a kérdőív módosításának következtében a felmérés során használt kérdőív egyes kérdései nincsenek összhangban a magyar modellel. Ugyanakkor a feltett kérdések azonossága lehetővé teszi a nemzetközi összehasonlítást.

Az Angyal Ádám és Csanda Júlia által véglegesített angol nyelvú kérdőívet fordítottam le magyarra, s ezzel kerestem meg a vállalatokat. A kérdőív hat részból áll.
Az elsố általános kérdésekkel foglalkozik, a második a vállalat tulajdonosi struktúrájára, a harmadik a társaság felsôvezetésére, a negyedik az igazgatóságra, az ötödik a felügyelőbizottságra vonatkozik. A hatodik rész a vállalat egyéb érintettekhez füződő viszonyát vizsgálja.

\section{A vizsgálandó vállalatok és a felmérés}

A kutatás kezdetén, a megkeresendô vállalatok kiválasztásánál, több szempontot is figyelembe vettem. A vállalat tevékenységét tekintve a humángyógyszergyártással foglalkozó társaságokra koncentráltam. Nem foglalkoztam tehát a gyógyszeriparhoz kötődő, de ahhoz nem tartozó gyógyszer-nagykereskedelmi vállalatokkal (pl. Hungaropharma Gyógyszerkereskedelmi Rt., Medimpex Gyógyszer-nagykereskedelmi Rt.) és biotechnológiai társaságokkal (pl. Solvo Biotechnology Inc., ComGenex Inc.). Emellett kutatásom nem terjedt ki az állatgyógyászati vállalatokra sem (pl. Phylaxia Pharma Rt., CEVA-Phylaxia Rt.).

A második - és talán legfontosabb - szempont az volt, hogy a felmérésben részt vevó vállalatnak részvénytársasági formában kell múködnie. Ez két okból lényeges. Egyrészt - a törvényi szabályozásnak is köszönhetóen - a vállalati kormányzás jellegzetességei ennél a társasági formánál figyelhetốk meg leginkább. Természetesen más társasági formák esetében is találkozhatunk a vállalati kormányzás jellemzố testületeivel, de mivel a törvény ezt nem teszi kötelezővé, így többnyire az egyszerúség kedvéért eltekintenek ezek alkalmazásától. A külföldi tulajdonosok esetében sokszor az tapasztalható, hogy magyarországi leányvállalatukat inkább kft. formában múködtetik éppen annak érdekében, hogy az adott vállalat társaságirányítási rendszere egyszerúbb lehessen ${ }^{13}$. A második ok az, hogy a kérdôív legtöbb kérdése egyértelmúen részvénytársaságokra vonatkozik, azaz más társasági formákkal nincsen összhangban.

Ez a szempont rögtön jelentősen leszúkítette a vállalatok körét, hiszen a gyógyszeripari cégek esetében is a külföldi anyacég által alapított magyarországi leányvállalat többnyire kft. formában múködik. Sốt arra is volt példa, hogy egy korábban részvénytársasági formában múködô magyar gyógyszergyárat az új (külföldi) tulajdonos kft.-vé alakított át (Pharmavit). A 3. táblázatból az is látszik, hogy Magyarország 200 legnagyobb vállalata közt szereplő nyolc gyógyszeripari cég közül négy (Novartis, Roche, Pfizer, GlaxoSmithKline) kft. formában múködik. Mind a négy társaság külföldi cég által alapított leányvállalat.

A kiválasztás harmadik szempontja az volt, hogy a felmérésnek lehetőség szerint le kell fednie az összes tôzsdén jelenlévő, humángyógyszer-gyártással foglal- 
kozó társaságot. Ez azért szükségszerú (vagy célszerú), mert a nyilvánosan múködố részvénytársaságok rendelkeznek a legösszetettebb társaságirányítási rendszerrel - többek között azért, mert rájuk vonatkozik a legtöbb szabály (törvényi szabályozás, Felelôs Vállalatirányítási Ajánlások). Emellett ezekról a társaságokról lehet a legtöbb információt beszerezni az interneten vagy egyéb forrásból. Ugyanakkor - eredeti tervemmel ellentétben - nem akartam kizárólag erre a csoportra leszúkíteni a vizsgálandó vállalatok körét, mivel a magyar tôzsdén nagyon kevés vállalat van jelen. A Budapesti Értéktôzsdén csupán négy gyógyszeripari társaság részvényeit jegyzik. Ez a négy vállalat a Richter Gedeon Rt., az Egis Rt., a HUMET Rt. és a Phylaxia Pharma Rt. Ezek közül a Phylaxia Pharma állatgyógyászati célokra gyárt gyógyszereket és egyéb készítményeket, tehát csak az elsố három társaság felel meg a kiválasztás kritériumainak.

Az utolsó szempont a vállalat mérete, piaci pozíciója és ismertsége volt. Ez a kritérium azonban „,másodlagosnak" mondható, mivel ez alapján csak bekerülni lehetett a vizsgálati körbe, kiesni nem. Ez a gyakorlatban annyit jelent, hogy ezt a szempontot csak abban az esetben vettem figyelembe, ha a vállalat nem felelt meg az elôző kritériumnak, azaz nem nyilvánosan múködő részvénytársaság.

Az értékesítés nettó árbevétele alapján a négy legnagyobb gyógyszeripari társaság a Richter, a Chinoin, a TEVA és az Egis. A magyar piacon elért piaci részesedés alapján is mind a négy vállalat elókelő pozíciót foglal el (lásd 1. táblázat - a Chinoin a sanofi-aventis vállalatcsoport része, ezért annak neve alatt szerepel a táblázatban). Azt is meg kell jegyezni, hogy ezen a négy társaságon kívül sem a magyar piac elsố húsz szereplője között, sem Magyarország kétszáz legnagyobb vállalkozása között nem szerepel humángyógyszergyártással foglalkozó, részvénytársasági formában múködő vállalat. Ez a négy társaság a magyar OTCpiac elsố tíz szereplője közt is megtalálható (lásd 2. táblázat). Ugyanakkor az OTC-piac tíz vezető vállalata közt szerepel egy ötödik részvénytársaság is: a Béres Rt. A Béres a teljes magyar gyógyszerpiacot tekintve nem rendelkezik jelentôs piaci részesedéssel, és egyéb mutatók alapján is (árbevétel, foglalkoztatottak száma, saját tőke stb.) a korábban említett társaságoknál jóval kisebb, de az OTC-piacon 2005-ben a hatodik legnagyobb részesedést mondhatta magáénak, és a társaság neve a fogyasztók körében is jól ismert.

A fenti kritériumoknak végül összesen hat vállalat felelt meg. Vannak olyan szempontok, amelyek alapján ez a csoport sem tekinthetố homogénnek (pl. nyilvános - zárt rt.; vényköteles (Rx) - OTC-termékek; originális
- generikus gyógyszerek ), de véleményem szerint a kutatás központi témáját - a vállalati kormányzás gyakorlatát - jól lehet vizsgálni az általam meghatározott kritériumok alapján kiválasztott vállalatoknál. Ugyanakkor azt is szem előtt kell tartani, hogy a most említett különbségek a vállalatok társaságirányítási gyakorlata között tapasztalható eltérések egy részét is magyarázhatják.

A fenti kritériumoknak tehát a következő hat vállalat felelt meg:

- Az összes kritériumnak megfelelt a Richter Gedeon Rt., amely Magyarország legnagyobb, és egyik legismertebb gyógyszergyára. A magyar piacon sokáig piacvezetô pozíciót töltött be, de ma is az elsôk között szerepel. Vényköteles és vény nélkül kapható termékeket egyaránt gyárt. A Richter számos originális gyógyszert fejlesztett ki, de generikus készítményeket is gyárt. A társaság jelen van a Budapesti Értéktôzsdén.

- A másik olyan vállalat, amely minden kritériumnak megfelelt, az Egis Rt. Az Egis sokáig a második magyar gyógyszergyár volt mind méretét, mind piaci pozícióját tekintve. 2005-ben a negyedik legnagyobb magyar gyógyszergyár, a negyedik legnagyobb piaci részesedéssel. A Richterhez hasonlóan az Egis is egyaránt foglalkozik Rx- és OTC-termékek elóállításával is, és a számos saját originális gyógyszer mellett generikumokat is gyárt. Az Egis részvényeit is jegyzik a BÉT-en.

- A Chinoin Rt. a sanofi-aventis csoport része. A francia központú sanofi-aventis vállalatcsoporthoz két magyarországi vállalat tartozik: a gyógyszermarketinggel és értékesítéssel foglalkozó sanofi-aventis és a kutatás-fejlesztéssel, vegyipari tevékenységgel és gyógyszergyártással foglalkozó Chinoin. A Chinoin zártkörúen múködő részvénytársaság, de Magyarország második legnagyobb gyógyszergyára, és a sanofi-aventis csoport a teljes magyar gyógyszerpiacot és az OTC-piacot tekintve is az elsó helyen áll. Emellett a Chinoin Rt. - az előzô vállalatokhoz hasonlóan - jól ismert a fogyasztók körében is. Originális és generikus kutató- és fejlesztômunkát egyaránt folytat a vállalat.

- A TEVA Gyógyszergyár Rt. Magyarország harmadik legnagyobb gyógyszergyára. A fogyasztók körében valószínúleg kevésbé ismerős a vállalat neve, de ez a megállapítás biztosan nem igaz a termékeire (pl. Naksol, Irix, Elmex, Bilobil). Ez annak köszönhető, hogy a TEVA Gyógyszergyár Rt. a korábbi debreceni Biogal és gödöllói HUMAN gyógyszergyárak megvásárlásával jött létre, és csupán 2005. január elseje óta múködik e név alatt. A TEVA zártkörúen múködő részvénytársaság, amely a teljes magyar gyógyszer- 
piacon a hatodik, az OTC-piacon a negyedik, a kórházak felé történő értékesítést tekintve pedig az elsô helyen áll. A TEVA - az eddig bemutatott vállalatokkal ellentétben - elsôsorban a generikus termékek gyártására és forgalmazására koncentrál.

- A Béres Gyógyszergyár Rt. OTC-termékek - azon belül is elsôsorban egészségmegốrző készítmények gyártására specializálódott. A Béres Gyógyszergyár egy zártkörúen múködő részvénytársaság, amely jóval kisebb, mint a fentebb bemutatott négy társaság, de - ahogy azt fentebb is említettem - az OTC-piacon a hatodik helyen áll, és emellett az ország egyik legismertebb vállalata. Legfontosabb termékük - amely miatt megalakult a vállalat - a Béres Csepp, amely az OTC-piac második legnagyobb forgalmú készítménye.

- A hatodik vállalat a HUMET Rt. A HUMET Rt. a Béres Gyógyszergyárnál is jóval kisebb, és valószínúleg a fogyasztók közül is kevesen ismerik. Ugyanakkor részvényeit jegyzik a Budapesti Értéktőzsdén, ezért mindenképp a vizsgálandó vállalatok köréhez tartozik. A HUMET vény nélkül kapható gyógyhatású készítményeket és azok hatóanyagait gyártja. A Béres Rt.-hez hasonlóan egy saját fejlesztésú, nyomelemekkel dúsított gyógyhatású készítmény (HUMET-R) köré szerveződött a vállalat.

A kritériumoknak még egy hetedik társaság, az ICN Magyarország Rt. is megfelelt volna. Azonban - valószínúleg a 2005-ben történt tulajdonosváltásnak köszönhetően - nem sikerült naprakész információkat szereznem erról a vállalatról, és az is kérdéses, hogy a változások után a gyógyszergyár milyen formában múködik tovább.

A felmérés során tehát a fent említett hat vállalatot kerestem meg a kérdốívvel, elsố körben e-mailen keresztuil. Ekkor csupán egy válasz érkezett. A kapcsolatfelvételt nehezítette, hogy több esetben a rendelkezésre álló információforrások sem közvetlen e-mail címeket, sem közvetlen telefonszámokat nem tartalmaztak, és azt is nehéz volt kideríteni, hogy kit kereshetek az üggyel kapcsolatban. A nyilvánosan múködô részvénytársaságok esetében ebból a szempontból valamelyest könnyebb volt a helyzet, hiszen az általuk üzemeltetett honlapok széles körú információkkal szolgáltak. Második körben telefonon próbáltam felvenni a kapcsolatot a társaságokkal, ami többnyire sikerült is. Az egyik vállalat esetében, egy személyes interjú keretében, közösen töltöttük ki a kérdôívet. További két társaság - többszöri megkeresést követôen - elektronikus formában küldte vissza a kitöltött kérdőívet. Az egyik cégtôl, sajnos semmilyen választ nem kaptam, és nem sikerült senkivel se beszélnem.
Az utolsó vállalat úgy ítélte meg, hogy a kérdőív egyes kérdései túlságosan bizalmas információkra kérdez rá, ezért végül nem töltötte ki azt. A végeredmény tehát négy kitöltött kérdőív a hatból, ami kétharmados válaszadási arány.

\section{A kérdốvek kiértékelése ${ }^{7}$}

Az alábbiakban a kitöltött kérdőívek alapján fogom értékelni és elemezni a vállalatok kormányzási gyakorlatát. Azoknál a társaságoknál, ahonnan nem kaptam válaszokat, megpróbálom ezeket pótolni a szabadon hozzáférhetố információk segítségével (pl. vállalati honlapok). Természetesen ilyen módon a kérdőívnek csak bizonyos kérdéseit tudom megválaszolni, ezért az elemzés során jelölni fogom, hogy egy adott fejezet hány társaság adataira épül. Az elemzés során azoknál a pontoknál, amelyek bizalmas információkat érintenek, a válaszokat a vállalatokra való hivatkozás nélkül kezelem. Azoknál a kérdéseknél, amelyek esetében az információ mindenki számára szabadon hozzáférhetô, és ahol ez segíti a pontosabb kép kialakítását, ott különkülön, vállalatonként is kitérek a válaszokra.

A kérdőíveket többnyire PR-feladatokat ellátó személy töltötte ki (kommunikációs vezetó, befektetői kapcsolattartó, PR-munkatárs), egy esetben pedig az igazgatóság elnöke. A kérdő́ivek kiértékelése során többször találkoztam azzal a problémával, hogy a kitöltő nem pontosan tudta, hogy mire vonatkozik a kérdés. Sajnos ebben szerepet játszhatott a kérdőív korábban már említett, a német és a magyar kormányzási rendszer eltéréseiból adódó pontatlansága is. Ugyanakkor az is okozhatta, hogy a kitöltő - munkaköréből adódóan - nem feltétlenül ismerte a vállalat vezetố testületeit, illetve társaságirányítási gyakorlatát. Azokon a helyeken, ahol a válasz egyértelmúen eltér a valóságtól, ott megpróbálom ezeket korrigálni, amennyiben más forrásból elérhető az információ. Azonban azt is szem előtt kell tartani, hogy mindezeknek köszönhetôen a bemutatott információk és a rájuk támaszkodó megállapítások torzulhatnak.

\section{Általános kérdések}

A magyar gyógyszeripar nagy hagyományokkal rendelkezik, és ezt a kérdőívek is igazolták. Ugyanis a hat vállalat közül négynek a története a XX. század elején kezdődött. A Richter Gedeont alapították a legkorábban, 1901-ben, majd a Chinoin jogelődje, az Alka következett 1910-ben. A TEVA Gyógyszergyár Rt. története 1912-ben kezdődött, ugyanis ebben az évben alapították a Rexet, a Biogal jogelődjét, és ugyancsak ebben az évben alakult meg a Phylaxia, amelyból 1954ben vált ki a HUMAN. 2005. január elseje óta a Biogal 
és a HUMAN közös neve TEVA. Az Egis jogelődjét, a Dr. Wandert 1913-ban alapították.

A fenti vállalatoktól nemcsak méretben, hanem múködésben és termékkínálatban is jelentôsen eltérô Béres és HUMET története is nagymértékben különbözik az eddigiektôl. Mindkettő egy saját kifejlesztésú gyógyhatású készítmény előállítására és forgalmazására jött létre. A HUMET jogelődjét 1983-ban, a Bérest 1989-ben alapították.

Értelemszerúen a vállalatok fố profilja mind a hat esetben a humángyógyszer-gyártás, bár a válaszok közt más megnevezések is szerepelnek (gyógyszeripar, vegyipar, gyógyszeralapanyag-gyártás). Az egyes társaságok profilja közt meglévő azonosságokat és különbségeket a bemutatásuk során már érintettem (pl. originális - generikus termékek). Most csupán a HUMET és a Béres specializálódását hangsúlyoznám ismét, amelynek köszönhetóen e két vállalat számára a teljes gyógyszerpiacnak csupán egy szúk szelete releváns. Ezzel szemben a négy nagy gyógyszergyár - a Richter, az Egis, a Chinoin és a TEVA - tevékenysége a gyógyszeripart gyakorlatilag - mind vertikálisan, mind horizontálisan - teljes egészében lefedi.

Ahogy azt a korábbi fejezetekben már bemutattam, a négy nagy gyógyszergyár Magyarország legnagyobb kétszáz (sớt legnagyobb száz) vállalata közt szerepel. A Richter 2005-ben 140 milliárd Ft-os forgalmat bonyolított, és több mint 5600 foót foglalkoztatott. A Chinoin forgalma 2005-ben 130 milliárd Ft körül alakult, és a cégnél 2300 fő dolgozott. A TEVA tevékenységére vonatkozóan csak 2004-es adatok állnak rendelkezésemre. Abban az évben a TEVA 86 milliárd Ft-os forgalmat ért el, és közel 1200 embert foglalkoztatott. Az Egis Rt. üzleti éve október 1-jétoól a következő naptári év szeptember 30-ig tart. Ennek megfelelóen a 2004. október 1-jétốl 2005. szeptember 30-ig tartó üzleti év folyamán a vállalat 73 milliárd Ft-os forgalmat realizált, és jelenleg közel 2700 főnek ad munkát.

Az elôzóeknél jóval kisebb vállalat a Béres Rt., amely a foglalkoztatottak számát tekintve mégis a nagyvállalati besorolás határán áll, hiszen jelenleg 250 fő dolgozik a társaságnál. A cég 2005. évi forgalma ötmilliárd Ft volt, ami szintén csupán töredéke a négy nagy gyógyszergyár árbevételének.

Ahogy a korábbiakban is említettem, a HUMET Rt. a legkisebb vállalat a hat közül. A társaság 2005ös forgalma 63 millió Ft volt, és 2005 végén 6, 2006. április elején 1 fót foglalkoztatott. Ez alapján a vállalat mikrovállalkozásnak minôsül. Azt is hozzá kell tenni azonban, hogy a szélsőséges adatok annak köszönhetók, hogy a kérdő́iv kitöltésekor a vállalat reorganizációja folyt. A vállalat ügyeivel ekkor is több ember foglalkozott (5-6 fó), de közülük csupán egy állt munkaviszonyban a társasággal.

A Richter, a Chinoin, az Egis és a TEVA forgalma az elmúlt öt évben gyorsan növekedett. A dinamikus növekedés a teljes magyar gyógyszerpiacra is igaz (lásd 1. ábra). A Béres Rt. forgalma mérsékelten növekedett ugyanebben az idôszakban, míg a HUMET Rt. mérsékelten csökkenő forgalomról számolt be.

A hat vállalat közül háromnak - a Richternek, az Egisnek és a HUMET-nek - a részvényeit jegyzik a Budapesti Értéktôzsdén. A Richter emellett a Londoni SEAQ International részvénypiacon is megjelent, és 1995-ben részvényeit a Luxemburgi Értéktőzsdén is bevezették.

\section{Tulajdonosi struktúra ${ }^{15}$}

A magyar gyógyszeriparban egyértelmú a külföldi tulajdonosok és befektetốk dominanciája, amit a kérdő́ivek is alátámasztanak. Azok a gyógyszeripari vállalatok, amelyeket nem külföldi cég alapított magyarországi leányvállalatként, többnyire külföldi tulajdonba kerültek az 1990-es években a privatizáció során. A nagy magyar gyógyszergyárakat jellemzóen szakmai befektetốk vásárolták meg. A Chinoin körülbelül 99,9\%-ban a francia sanofi-aventis birtokában van. A TEVA Gyógyszergyár Rt. több mint 99\%-os tulajdonosa az izraeli TEVA Pharmaceutical Industries Ltd.

$\mathrm{Az}$ Egis Rt. tulajdonosi struktúrája nem ennyire koncentrált, de a többségi tulajdonos itt is egy külföldi szakmai befektető, a francia Servier gyógyszergyár 50,91\%-os részesedéssel. A francia cég egyben az Egis stratégiai partnere is. Ugyanakkor a Servier-rel együtt a külföldi intézményi és magánbefektetốk aránya az Egis tulajdonosi struktúrájában $93,88 \%$. A részvények 6,07\%-a hazai pénzintézetek, egyéb vállalatok és magánszemélyek kezében van. A vállalat felsôvezetése a részvények 0,06\%-át birtokolják.

A Richter Gedeon az egyetlen a nagy magyar gyógyszergyárak közül, amelyik szakmai befektetố nélkül múködik. A tulajdonosi szerkezete is kevésbé koncentrált, azonban ennél a vállalatnál is a külföldi befektetők vannak túlsúlyban. A legnagyobb tulajdonos még mindig az ÁPV Rt. 25\%-os tulajdoni hányaddal. A részvények 20,18\%-a a Bank of New York kezében van. Az ÁPV Rt.-n és a Bank of New York-on kívül nincsen más részvénytulajdonos bejegyezve 5 százaléknál magasabb tulajdoni hányaddal. A részvények összesen 67\%-a van külföldi intézményi és magánbefektetôk, és 8\%-a hazai intézményi és magánbefektetốk kezében. A vezetô testületek (igazgatóság és felügyelóbizottság) és az ügyvezetés összesen $0,06 \%$-os tulajdonosi részesedéssel bír. 
A két kisebb vállalat a tulajdonosi szerkezetet tekintve is eltér a nagyoktól, elsődlegesen azért, mert esetükben a hazai tulajdonosok dominálnak. Ugyanakkor a két társaság tulajdonosi struktúrája egymástól is alapvetôen különbözik. A Béres Rt. - a vállalat történetét tekintve nem meglepó módon - 100\%-os családi tulajdonban van. Ezzel szemben a hat vizsgált vállalat közül a HUMET rendelkezik a legkevésbé koncentrált tulajdonosi struktúrával. A társaságnak két tulajdonosa rendelkezik 5\%-nál magasabb tulajdoni hányaddal: a „Dr. Csucska Elek” Kutatási és Fejlesztési Alapítvány $(15,01 \%)^{16}$ és a vállalat igazgatóságának elnöke, Civin János $(5,05 \%)$. A vállalat felsóvezetése és családtagjaik, valamint az igazgatóság és a felügyelőbizottság tagjai összesen (Civin Jánossal együtt) a részvények $10 \%$-át birtokolják. A részvények $80 \%$-a egyéb hazai vállalatok és magánszemélyek kezében van (ideértve a legnagyobb tulajdonost, az alapítványt is), és csupán a maradék $10 \%$ van külföldi vállalatok és magánszemélyek tulajdonában.

A vállalatok tulajdonosi szerkezetét foglalja össze a 4. táblázat:

A vizsgált társaságok tulajdonosi struktúrája

\begin{tabular}{|l|c|c|c|c|c|c|}
\hline & Chinoin & TEVA & Egis & $\begin{array}{c}\text { Rich- } \\
\text { ter }\end{array}$ & Béres & $\begin{array}{c}\text { HU- } \\
\text { MET }\end{array}$ \\
\hline Családi tulajdon & - & - & - & - & $100 \%$ & - \\
\hline $\begin{array}{l}\text { Vezetó testületek } \\
\text { és felsóvezetés }\end{array}$ & - & - & $0,1 \%$ & $0,1 \%$ & - & $10 \%$ \\
\hline Állami tulajdon & - & - & - & $25,0 \%$ & - & - \\
\hline $\begin{array}{l}\text { Hazai intézményi } \\
\text { és magánbefektetók }\end{array}$ & $0,1 \%$ & $0,1 \%$ & $6,1 \%$ & $7,9 \%$ & - & $80 \%$ \\
\hline $\begin{array}{l}\text { Külföldi intézményi } \\
\text { és magánbefektetók }\end{array}$ & $\mathbf{9 9 , 9 \%}$ & $\mathbf{9 9 , 9 \%}$ & $\mathbf{9 3 , 9 \%}$ & $\mathbf{6 7 , 0 \%}$ & - & $\mathbf{1 0 \%}$ \\
\hline
\end{tabular}

Mind a hat vizsgált vállalat egy vállalatcsoport része. A tulajdonosi struktúrából következóen a Chinoin, a TEVA és az Egis egy külföldi vállalatcsoport tagja, ami szintén megegyezik a magyarországi nagyvállalatok általános jellemzóivel. Ugyanakkor azt meg kell jegyezni, hogy az Egis világszerte több leányvállalattal is rendelkezik. Ugyanez igaz a Richterre is, amely így az anyavállalat szerepét tölti be a vállalatcsoporton belül. A Béres Gyógyszergyár Rt. a Béres Csoport tagja, de ez a kutatás szempontjából nem releváns, hiszen a teljes csoport a Béres család kezében van. A HUMET Rt.nek az Egyesült Államokban van egy leányvállalata.

A hat vállalat közül csak a Béres Rt. tekinthetố családi vállalkozásnak, amely 100\%-ban a Béres család tulajdonában áll. Ennek megfelelően a család képvisel- tetve van a vezetô testületekben és a felsôvezetésben is, és a család több generációja is aktív a cégben. Ugyanakkor az alapító - a másik öt társasághoz hasonlóan - már nem aktív a vállalatban.

\section{Felsóvezetés ${ }^{17}$}

A vállalatok közt nem volt nagy különbség a felsố vezetés létszámát tekintve. Ebból arra lehet következtetni, hogy a jóval nagyobb vállalati méret nem feltétlenül jár együtt nagyobb létszámú menedzsmenttel. A társaságok operatív vezetését jellemzóen 5-7 fő látja el. Az öt vállalat közül egyben öt, egyben hat és kettóben hét fő alkotja a felsővezetést. Az ötödik társaság, a Béres - amely ráadásul a második legkisebb vállalkozás az ötból - a kérdőívben megadott válasz szerint 12 fốs menedzsmenttel rendelkezik, ugyanakkor a cég honlapján csupán hat fő szerepel a vezetôség bemutatásánál. Ha mégis a 12 igaz, az nagyon meglepó a vállalat méretétől függetlenül is, annak ismeretében pedig még inkább. A jelentős különbség valószínúleg abból adódik, hogy a kérdőív kitöltôje a hierarchiát tekintve lejjebb húzhatta meg a határt a felsővezetés meghatározásakor. A

4. táblázat bizonytalanságot az is okozhatja, hogy a felsôvezetés nem tartozik a jog által meghatározott vezetố testületek közé, ezért nincsen pontosan körülhatárolva. Ez a probléma a nagyobb vállalatoknál nem jellemző, hiszen ott a menedzsment múködése és összetétele többnyire egyértelmúen definiált.

Az öt vállalat közül háromban nốk is jelen vannak a felsô vezetésben, de mindenhol a férfiak vannak többségben. Ugyanakkor az egyik vállalatnál a menedzsment elsố embere, a vezérigazgató nő.

A vizsgált vállalatoknál nem jellemzô a külföldi jelenlét a felsôvvezetésben. Az öt társaság közül csak a Chinoin menedzsmentjében van jelen két külföldi vezetô. A két kisebb vállalat esetében a külföldiek hiánya érthető, hiszen ezeknél a társaságoknál a tulajdonosok közt nincsenek, vagy csak kismértékben vannak jelen külföldiek. A Richter esetében a külföldi szakmai befektetô hiánya könnyen megmagyarázza a dolgot. Az Egis esetében a külföldi szakmai befektetô valószínúleg úgy ítéli meg, hogy a társaság ügyvezetése önállóan is megfelelô teljesítményt produkál. A vállalat rendszerváltozás óta elért eredményei legalábbis erre engednek következtetni. Természetesen a kiváló teljesítmény a Chinoinra is igaz, itt valószínúleg a tulajdonos vállalatcsoport összetételében utóbbi években 
bekövetkezett jelentôs változások (fúziók) indokolják a külföldiek jelenlétét.

Bár arra a kérdésre, hogy hány éve tölti be a jelenlegi vezérigazgató ezt a tisztséget, többféle válasz érkezett, mégis úgy gondolom, hogy a gyógyszeriparban inkább a hosszú távú vezetôi megbízatás és a vállalaton belüli előmenetel jellemző. A Richter vezérigazgatója 14 éve tölti be ezt a tisztséget, és korábban is több éven át - különböző vezetô pozíciókban - dolgozott a társaságnál. Az Egis jelenlegi vezérigazgatója csupán alig egy éve látja el ezt a feladatot, de azt megelőzően is több éve a vállalatnál dolgozott. Dr. Orbán István, a társaság korábbi - 2005 januárjában váratlanul elhunyt - vezérigazgatója több mint negyven éven át volt a vállalat munkatársa, ebból 24 évig az ügyvezetés elsố embere. A Chinoin vezérigazgatója csupán másfél éve tölti be posztját, de ez valószínúleg a korábban már említett átalakulásoknak köszönhetô. A két kisebb vállalat erre a kérdésre nem adott választ, de az egyéb források és a társaságok története alapján arra következtethetünk, hogy a Béres Gyógyszergyár Rt. vezérigazgatója a vállalat megalakulása, azaz 1989 óta tölti be ezt a tisztséget, és az is valószínúsíthető, hogy a HUMET vezetését is ugyanazok látják el évek óta. Általában is elmondható, hogy ezeknél a vállalatoknál erős az összetartozás és a csapatszellem, és a hierarchia minden szintjén rendkívül alacsony a fluktuáció. Ebból adódik, hogy a vállalatok munkatársainak többsége több éve (egyes esetekben évtizede) dolgozik az adott társaságnál, és a hierarchia felsốbb szintjein lévô embereket jellemzóen a vállalaton belülról választották. A kívülról érkező vezetốk sokkal ritkábbak a gyógyszergyárak körében, mint más iparágakban, s ezt a kérdőívek is igazolták.

A vizsgált vállalatok körében nem jellemzô a felsôvezetés tagjainak részvényopciókkal történő jutalmazása. A kérdésre négy válasz érkezett, és a négy társaság közül csupán egynél élnek ezzel a motivációs eszközzel, ami a tulajdonosi struktúrán is meglátszik. A menedzserek részvényopciókkal történő jutalmazását a corporate governance egyes szakértói eltérő módon ítélik meg. Vannak, akik az előnyeit (növekvő részvényárfolyam és nyereség), s vannak, akik a hátrányait (rövid távú pénzügyi célok előtérbe kerülése) hangsúlyozzák. A vizsgált vállalatoknál tapasztaltak azt mutatják, hogy „,az intézmények nem tartják szükségesnek a menedzsment tulajdonosi érdekeltségének bekapcsolását a motivációs eszköztárukba"18. Ezt a gyakorlatot egyes vállalatok esetében magyarázhatja a domináns külföldi szakmai befektetôii, vagy családi tulajdon. A vállalati kultúra korábban már említett jellegzetessége is lehet ennek oka, azaz az erôs összetartás és a vezetés válla- laton belül történő „kinevelése”. Ennek köszönhetően ugyanis biztosított a menedzsment vállalat iránti elkötelezettsége részvényopciók nélkül is. A részvényopciókkal történó jutalmazás eszközével élő vállalat esetében is megtalálható ennek a gyakorlatnak a magyarázata. Egyrészt ez a társaság rendelkezik a legkevésbé koncentrált tulajdonosi struktúrával. A második - az elôzônél fontosabb - indok az, hogy a vállalat komoly likviditási problémákkal küzd az utóbbi években, aminek következtében több tartozását is részvénykibocsátással próbálta fedezni. Ennek megfelelôen a menedzsment tagjai is fizetésüket részben vagy egészben - készpénz helyett - részvények formájában kapják/kapták.

A beérkezett négy válasz alapján a felsôvezetés megbeszéléseinek rendszeressége szintén nem függ a vállalat méretétól. Az egyik legnagyobb vállalat menedzsmentjének tagjai csupán egyszer tartanak megbeszélést havonta, további két társaságnál pedig a találkozók száma havonta négy - azaz hetente egy. A legkisebb vállalkozás vezetői havonta kilencszer tanácskoznak egymással.

A közlemények számát tekintve a válaszok jelentősen eltértek egymástól. Ezek alapján egyes vállalatok nagyon kevés (pl. 3) közleményt, vagy egyet sem publikáltak az elmúlt év során. Csupán egy vállalat volt, amely nagyobb számot (54) adott meg válaszként. Azonban többnyire ezek a válaszok nem felelnek meg a valóságnak, hiszen például egy tőzsdén jegyzett vállalatnak számos információt kell közzétennie múködése során, s a kötelezettségeken túl is több hírt a nyilvánosság elé tár (pl. gyorsjelentések, személyi változások, felelős vállalatirányításra vonatkozó nyilatkozat, egyéb események stb.). A zártkörúen múködô részvénytársaságok honlapján is külön oldal tartalmazza a vállalat sajtóközleményeit. Ezek alapján az mondható, hogy a társaságok mindegyike számos (kb. 10-60) közleményt tett közzé 2005-ben. A félreértést az okozhatja, hogy a kérdőív nem határozta meg pontosan, hogy mit is ért közlemény alatt.

Az öt vállalatból kettő rendelkezik befektetói kapcsolatokkal foglalkozó, önálló részleggel, egy esetében pedig a jogi osztály végzi az ilyen jellegú feladatokat. Ez a gyakorlat könnyen megmagyarázható a vállalatok múködése és tulajdonosi szerkezete alapján. Ugyanis ilyen jellegú, önálló részleggel a két nagyobb méretú, tôzsdén jelen lévő vállalat rendelkezik, amelyek esetében a részvényeket számos tulajdonos birtokolja, és a részvények tôzsdei forgalma is jelentôs. A Chinoin esetében a befektetôi kapcsolattartás nyilván kevesebb feladatot jelent, hiszen a vállalat részvényeinek $99,9 \%$-a egy tulajdonos kezében van. Ennek megfelelóen a társaság nem rendelkezik erre specializálódott, önálló 
részleggel, hanem a jogi osztály foglalkozik az ilyen jellegú kérdésekkel. A Béres esetében a 100\%-os családi tulajdon teljesen feleslegessé teszi egy ilyen osztály múköodtetését. Bár a HUMET jelen van a tózsdén, és részvényei széles körben terítettek, mégsem rendelkezik befektetôi kapcsolattartással foglalkozó részleggel. Ennek oka egyszerúen az, hogy a vállalat olyan kicsi, hogy nem rendelkezik különböző területekre specializálódott osztályokkal. A Budapesti Értéktôzsde és a társaság honlapja is azt mutatja, hogy a kapcsolattartással a vállalat igazgatóságának elnöke foglalkozik.

A külsố könyvvizsgálóra vonatkozó kérdésre négy társaság válaszolt. A két nagyobb vállalat nem változtatja rendszeresen külső könyvvizsgálóját, ami valószínúleg annak köszönhető, hogy méretükból adódóan vélhetôen könyvvizsgáló társasággal állnak szerződésben, amelyet nem kötelezô rendszeresen változtatni. A kisebb vállalatok közül az egyik 2-3, a másik 4-5 évente cseréli külső könyvvizsgálóját.

A következő kérdések a felsóvezetés és a felügyelóbizottság (FB) közti kapcsolatra vonatkoztak. Ezeknek a kérdéseknek a német rendszerben nagyobb a relevanciája, hiszen ott - a magyar modellel ellentétben - a felügyelóbizottság rendelkezik a legnagyobb hatalommal. A felsố vezetés a négy válaszadó vállalat közül kettônél évente csupán egyszer, egynél pedig évente négyszer köteles a felügyelőbizottságnak jelenteni. A leggyengébb kapcsolat a Chinoin menedzsmentje és felügyelőbizottsága között figyelhetô meg, mert ott amellett, hogy évente csak egyszer jelent a menedzsment az FB-nek, a vezérigazgató is csupán időnként vesz részt az FB ülésein, egyéb felsővezetô pedig soha. A társaságnál a felügyelőbizottságnak bevallottan csak szimbolikus szerepe van. A Béresnél is csak egyszer jelent évente a menedzsment az FB-nek, de itt a vezérigazgató és egyéb felsôvezetốk is rendszeresen részt vesznek az FB ülésein. Az Egis felső vezetése évente négyszer jelent a felügyelóbizottságnak, és a vezérigazgató idônként, egyéb felsố vezetố pedig mindig részt vesz az FB-üléseken. A részvételek ellenére azt mondhatjuk, hogy a három társaság esetében az FB nem áll szoros kapcsolatban a felsôvezetéssel, hiszen a jelentések száma nagyon alacsony. A menedzsment tagjai a HUMET-nél is rendszeresen részt vesznek az FB ülésein, ugyanakkor a jelentéseket tekintve irreálisan magas számot adott meg a társaság. Eszerint évente 45-ször jelent a felsővezetés az FB-nek, ami majdnem hetenkénti gyakoriságot jelent. Amennyiben nem elírásról van szó, akkor csak a vállalat nehéz helyzete, a reorganizációs folyamat indokolhatja a jelentések nagy számát, de a 45 még így is rendkívül meglepő lenne.

\section{Igazgatóság}

Az igazgatóság az 1997-es Gt szerint a részvénytársaság legfőbb ügyvezető szerve, amely legalább három, legfeljebb tizenegy természetes személy tagból áll.

Az igazgatóságra vonatkozóan az öt vállalat közül kettő szélsőséges választ adott meg, ezért ezeket mellőzöm az ügyvezető testületek összetételének elemzése során. Az egyik a Chinoin volt, amely élt a törvény által nyújtott lehetôséggel, miszerint zártkörúen múködô részvénytársaságként nem kötelező igazgatóságot választania. Ebben az esetben az igazgatóság törvényben meghatározott jogait a vezérigazgató gyakorolja. Gyakorlatilag olyan, mintha egyszemélyes igazgatósága lenne a vállalatnak. Ez egyben azt is jelenti, hogy a vállalat múködését teljes egészében a menedzsment irányítja. A másik szélsőséges válasz a Bérestól érkezett, miszerint a társaság igazgatósága 12 fóboól áll, ami azért nem lehetséges, mert a Gt. 11 fóben maximálja a testület létszámát.

A másik három társaság igazgatóságainak létszáma között jelentôs különbségek voltak. A létszámok a következók: HUMET - 4; Richter - 9; Egis - 11. Látható, hogy a két nagyobb vállalat testületei nagyobb létszámmal múködnek, s az Egis esetében ez eléri a törvény által meghatározott felső korlátot. A testületek összetételéból az látszik, hogy az igazgatóságokban a nók még kevesebb szerepet kapnak, mint a felsővezetésben. A három testületben összesen egy nó kapott helyet. A HUMET igazgatóságában - a felsővezetéséhez hasonlóan - nincsen külföldi tag. Ezzel szemben mind a Richter, mind az Egis igazgatóságában külföldiek is helyet kaptak, sốt mindkét testület elnöke is külföldi. A Richter igazgatóságában a 9 tag közül 2, az Egisnél a 11-ból 6 fó külföldi. Az Egis esetében mind a 6 külföldi igazgatósági tag a többségi tulajdonost, a Serviert képviseli a vállalatban.

A testület összetételét tekintve a Richter igazgatósága a legheterogénebb. Jelenleg a felsóvezetók közül csak a vezérigazgató van jelen az igazgatóságban. További egy fó korábban a menedzsment tagja volt, de 2006 januárjától stratégiai tanácsadóként dolgozik a társaságnál. A kérdő́ívben szereplő kategóriák mindegyikébe maximum egy fó került be. A további tagok elsődleges jellemzói a következók: gazdasági jogász; egy másik vállalat igazgatóságának elnöke; egyetemi oktató; állam (ÁPV Rt.) - mint domináns tulajdonos - képviselője; egy külföldi vállalat igazgatóságának tanácsadója; orvos; hivatásos diplomata. Ezzel szemben az Egis igazgatósága - a nagyobb létszám ellenére - sokkal homogénebb. A 11 fóból négyen a vállalati felsôvezetés tagjai - köztük a vezérigazgatóval -, a hat külföldi tag a többségi tulajdonost képviseli, a tizen- 
egyedik tag pedig egyetemi oktató. A HUMET igazgatósága kisebb, csupán 4 főből áll. Meglepő, hogy a válaszok alapján a testületnek nincsen belsố tagja. A négy fốból kettố másik vállalat felsôvezetôje, egy gazdasági jogász és egy tudományos munkatárs (egyetemi hallgató). A HUMET igazgatóságában nincs olyan tag, aki jelentős tulajdonnal rendelkező céget vagy személyt képvisel. Azonban azt is meg kell jegyezni, hogy ennél a társaságnál a legnagyobb a vezetố tisztségviselők tulajdoni hányada (lásd fentebb). Mind a három testület tagjai közt vannak olyanok, akik más társaságok igazgatóságában vagy felügyelóbizottságában is tagok. Az Egis esetében ez mind a 11 igazgatóra igaz.

Az elmondottak alapján azt lehet mondani, hogy a három társaság megfelel annak a nemzetközi és hazai tendenciának, hogy az igazgatóságban a külső tagok vannak túlsúlyban. Azt is érdemes megjegyezni, hogy egyik társaságnál sem kaptak helyet az igazgatóságban az egyéb érintettek (pl. bank, ügyfél, beszállító) képviselői. Emellett a domináns tulajdonos - tulajdoni hányadától is függóen - többnyire képviselteti magát az igazgatóságban. Ez igaz a Béresre is, ahol az igazgatóság elnöke ifj. Dr. Béres József. A lényeget - a társaság ügyvezetésének befolyásolását - tekintve igaz a Chinoinra is, azzal az eltéréssel, hogy ott - igazgatóság híján - a felsôvezetésben - amely ebben az esetben a vállalat ügyvezetése - kaptak helyet a tulajdonos képviselói.

A négy vállalat (Richter, Egis, HUMET, Béres) egyikénél sem ugyanaz a személy tölti be az igazgatóság elnöki pozícióját és a vezérigazgatói tisztséget, ugyanakkor három esetben a vezérigazgató az igazgatóság szavazati joggal rendelkező tagja. Ez alól csak a HUMET kivétel, ami valószínúleg szintén a vállalat jelenlegi nehéz helyzetével magyarázható, hiszen a korábbi években a HUMET igazgatóságában is jelen volt a társaság vezérigazgatója. Az elnöki és vezérigazgatói pozíciók szétválasztása azt mutatja, hogy a társaságok többre értékelik a menedzsment hatékony testületi ellenőrzésének előnyeit, mint a hatalom egy kézben való koncentrációjából eredô hasznokat.

Ugyancsak nem igaz egyik vállalatra sem, hogy az igazgatóság elnöke a vállalat egy korábbi vezérigazgatója. A társaságok elnökei jellemzően nem olyan régóta töltik be posztjukat, mint a vezérigazgatók, de ebben a tekintetben is hosszabb távú megbízatásokat valószínúsíthetünk. Az igazgatóságok jelenlegi elnökei 6-10 éve töltik be ezt a tisztséget.

Az igazgatósági ülések gyakoriságára vonatkozóan szintén szélsôséges válaszok születtek. Az Egisnél a testület évente csupán háromszor ülésezik, ami valószínúleg a külföldi tagok nagy számának köszönhető, hiszen a nagy távolságok miatt nehézkesebb egy ilyen találkozó létrehozása. Ugyanakkor ennek fényében meglepő, hogy a testület egyszer sem hozott hivatalos döntést az igazgatósági üléseken kívül (pl. telefonkonferenciák, e-mailek, fax segítségével). Ez a gyakorlat a felsôvezetés hatalmát erôsíti, ami azért különös, mert a menedzsmentben - az igazgatósággal ellentétben - a többségi tulajdonos nem képviselteti magát. Ellentmondásosnak látszik a dolog, hiszen annak ellenére, hogy a társaság igazgatósága nagy létszámmal múködik, és a tagok közt túlsúlyban vannak a többségi tulajdonos küldöttei, az igazgatósági ülések gyakorisága alapján úgy tünik, hogy a testület mégsem játszik komoly szerepet a vállalat múködtetésében. Ezzel szemben a HUMET igazgatósága 17-szer ülésezett 2005-ben, ami azt mutatja, hogy a testületnek erős beleszólása van a társaság ügyvezetésébe. Az is érdekes, hogy ennél a vállalatnál 13-szor hoztak hivatalos döntést igazgatósági üléseken kívül, és ez az egyetlen társaság, ahol a szokásos igazgatósági ülések elôtt általában tartanak különálló előkészítő üléseket is. A Béres igazgatósága a válasz szerint 40 ülést tartott az elmúlt évben, ami ismét irreálisnak túnik. Ez azt jelentené, hogy a testület szinte minden héten ülésezett. Ilyen gyakoriság mellett a testület minden bizonnyal az operatív irányításban is részt vesz.

A társaságok gyakorlata azt támasztja alá, hogy a magyar vállalatok körében még mindig nem alakult ki az igazgatósági állandó bizottságok rendszere. A négy igazgatóság közül csak a Richter ügyvezetô testületében múködnek állandó bizottságok - vállalatirányítási és javadalmazási bizottság -, s ezek is csupán 2004 óta. Ugyanakkor mind a négy testületben a tagok egyértelmúen meghatározott munkamegosztás szerint végzik munkájukat. A vizsgált vállalatok esetében az igazgatóság jellemzően nem rendelkezik a vezérigazgató munkájára vonatkozó leírással. Az igazgatóságok többsége rendszeresen értékeli a felsôvezetést, azonban saját munkájára vonatkozóan ezt a legtöbb esetben nem teszi meg. Az igazgatósági tagok javadalmazásával kapcsolatban három válasz érkezett. Két vállalat esetében a testület tagjai fix összegú, éves alapdíjban részesülnek. A harmadik társaságnál az igazgatóság tagjai - a menedzsmenthez hasonlóan - részvényopciókat kapnak munkájukért.

A fejezet utolsó kérdéseinél az igazgatóságban előforduló konfliktusok gyakoriságát és a testület közremúködését kellett szubjektív módon értékelni. A három válaszadó vállalat közül egynek az igazgatóságában egyáltalán nem jellemzók a konfliktusok. Ennek valószínúleg a korábban már említett hosszú távú megbízatások és a testület tagjainak összeszokottsága a legfőbb oka, de részben magyarázhatja az is, hogy az igazga- 
tóság nem játszik fontos szerepet a társaság múködtetésében, és a menedzsment eredményesen múködteti a vállalatot. A második vállalat ügyvezetố testületében is csak ritkán fordulnak elô nézeteltérések, jellemző́en azzal kapcsolatban, hogy mi a legjobb a társaság számára, és azt hogyan valósítsák meg. A harmadik vállalatnál ezzel a két kérdéssel, és általában az igazgatósági döntésekkel kapcsolatban gyakoriak a konfliktusok, de ez minden bizonnyal a társaság speciális helyzetével magyarázható, és semmiképp sem tekinthetó jellemzőnek a gyógyszeripari vállalatok körében.

Az igazgatóság közremúködésével kapcsolatban a három vállalat két szélsôséges pozíciót foglal el. A nagyobbik vállalat esetében az igazgatóságnak nincsen komoly szerepe a kapcsolatépítésben és a lobbizásban, és vezetési, jogi, pénzügyi, múszaki és piaci kérdésekben sem ad tanácsokat. A testület feladata sokkal inkább az eredmények és a döntések ellenôrzése, valamint a felsővezetés kinevezése/leváltása. Ezzel szemben a két kisebb vállalat igazgatósága jelentős mértékben hozzájárul a kapcsolatépítéshez, fontos szerepet játszik a társaság múködtetésében és ellenőrzésében, ugyanakkor egyik esetben sem feladata a felsővezetés leváltása. Ezek alapján úgy túnik, hogy a vállalat mérete alapvetően befolyásolhatja az igazgatóság szerepét, de a válaszok kis száma miatt nem lehet általánosítani.

\section{Felügyelóbizottság}

A részvénytársaság múködésének ellenôrzését a felügyelőbizottság látja el, amely egy minimum 3, maximum 15 fóből álló testület.

A felügyelóbizottságok összetételére vonatkozóan öt vállalatról rendelkezem információkkal, de a Bérestól kapott válaszok, sajnos, ebben az esetben is egyértelmúen hibásak, hiszen ezek szerint a társaság felsôvezetésének tagjai is jelen vannak az FB-ben, amit a törvény nem tesz lehetôvé, és a munkavállalói küldöttek aránya nem éri el a 30\%-ot, ami ebben az esetben szintén nem lehetséges. Emiatt az alábbiakban csak a másik négy társaság felügyelóbizottságának összetételét vizsgálom.

A Chinoin esetében a felügyelóbizottságnak csupán szimbolikus szerepe van, azaz kizárólag a törvényi kötelezettség miatt múködik. Ennek megfelelően a minimális létszámmal, 3 fóvel múködik, akikból 2 a külföldi tulajdonost (sanofi-aventis) képviseli, a harmadik pedig a munkavállalók küldöttje. Mind a három fô férfi. Szintén a jelképes szerepet igazolja, hogy az FB 2005-ben csak egy ülést tartott, és feladatköre kizárólag az üzleti eredmények és döntések ellenőrzésére szorítkozik. Mivel a társaságnál igazgatóság sem múködik, így egyértelmú, hogy a felsôvezetés kezében összpontosul minden hatalom, amiben azonban jelen vannak a külföldi tulajdonos képviselôi. Ebból az is következik, hogy a tulajdonos valószínúleg alapvetôen meghatározza a vállalat múködésének irányait.

A HUMET felügyelố bizottsága 4 fóboól áll, akik közt nincsen se külföldi, se nô, se munkavállalói küldött. Ez ebben az esetben lehetséges, hiszen munkavállalói küldötteknek csak akkor kell helyet biztosítani az FB-ben, ha a vállalat foglalkoztatottjainak száma eléri a 200 fốt. Érdekes ugyanakkor, hogy - a társaság igazgatóságához hasonlóan - ebben a testületben sincsenek jelen domináns tulajdonost képviselő személyek.

Az Egis felügyelóbizottsága 8 fớból áll. Ebból 3 tagot a munkavállalók választottak, 1 tag nô, és 1 fó külföldi. Az FB esetében az összetétel sokkal heterogénebb, mint a társaság igazgatóságánál. A vállalat 3 szellemi dolgozója mellett helyet kapott az FB-ben más vállalat felsốvezetôje, gazdasági jogász, egyetemi oktató, egy vegyészmérnök és egy bank képviselője. A külföldi tag a többségi tulajdonost képviseli a bizottságban.

A Richter felügyelőbizottsága szintén 8 foóból áll, amelyból 3 tagot ebben az esetben is a munkavállalók delegáltak. A 8 tagból 2 nô, külföldiek azonban nincsenek a bizottságban. Az FB összetétele itt is heterogénnek mondható: a vállalat 3 szellemi dolgozója mellett az FB tagjai közt találhatunk egy egyetemi oktatót, egy tanácsadót, egy gyógyszerészt, és két tag más vállalatban tölt be vezetó pozíciót.

A testületek összetételéból az látszik, hogy a nốk itt is kisebbségben vannak. Érdekes, hogy a tulajdonosok csak két vállalat felügyelóbizottságában vannak jelen, és csak az egyikben vannak túlsúlyban. A Richter és a HUMET esetében valószínúleg ezt is a szórt tulajdonosi struktúra magyarázza. Ugyanakkor az Egis igazgatóságának összetételét tekintve meglepó, hogy az FB-ben csupán egy fó képviseli a többségi tulajdonost. Az egyéb érintettek többnyire a felügyeló bizottságokban sem kaptak helyet, hiszen a négy testület közül csupán egyben van jelen egy stakeholder (egy bank) képviselóje.

Az FB elnöki megbízatásának hosszára - a többi vezetố pozícióhoz hasonlóan - a hosszú táv jellemzô. Az öt vállalat közül kettônél 6, egynél 15 éve ugyanaz a személy a felügyelóbizottság elnöke. A Chinoinnál nem tudtak erre a kérdésre válaszolni, de valószínúsíthetô, hogy - a vezérigazgatói pozícióhoz hasonlóan az FB elnöke is a tulajdonos vállalatcsoport átalakulása óta tölti be tisztségét. A HUMET-nél még nincs egy éve, hogy kinevezték az FB elnökét, de ez is nyilván a vállalat múködésében bekövetkezô drasztikus változásoknak köszönhetó. 
A felügyelóbizottsági ülések gyakoriságára vonatkozóan, sajnos, csak a Chinointól érkezett válasz, amelyet fentebb már bemutattam. A felügyelóbizottságok múködésére még kevésbé jellemző a vállalatirányítás korszerú és formalizált módszereinek (pl. bizottsági rendszer, írott szabályok, rendszeres önértékelés) alkalmazása, mint az igazgatóságokra. Ugyanakkor a vállalatok többségére igaz, hogy az FB rendszeresen értékeli a felsővezetés munkáját. Az FB/tagok javadalmazásával kapcsolatban három válasz érkezett, amelyek azt mutatják, hogy itt is - az igazgatóságokhoz hasonlóan - az éves fix díj jellemzó. Ezt a gyakorlatot két vállalat követi, a harmadik esetében a javadalmazás az üléseken való részvételtól függ.

A felügyelőbizottságokban nem jellemzók a konfliktusok. Ez részben - az igazgatóság fejezetében leírtakhoz hasonlóan - magyarázható a testületi tagok összeszokottságával, de valószínúleg részben annak is köszönhetô, hogy az FB jellemzóen ellenôrző feladatokat lát el, azaz nem kell a vállalat stratégiájára, múködésére vonatkozó döntéseket hoznia. A felügyeló bizottságok közremúködését tekintve hasonló a kép, mint az igazgatóságok esetében, azaz a kisebb társaságoknál nagyobb szerepe van a testületnek a kapcsolatépítésben és a tanácsadásban, mint a nagyvállalatoknál, de az igazgatóság a kisebb cégek esetében is fontosabb testület. Az FB legfontosabb funkciója minden esetben az üzleti eredmények és döntések ellenórzése, ami megfelel a törvény által meghatározott feladatának. Az FB egyik vállalat esetében sem jogosult a felsôvezetốk leváltására.

\section{Egyéb érintettek}

A kérdőív utolsó blokkja azt vizsgálta, hogy az egyéb érintettek mennyire befolyásolják a vállalat társaságirányítását. Ennek mértékét egy 1-tôl 4-ig terjedő skálán kellett megadni, ahol az 1-es nagyon erôs befolyást jelent, a 4-es pedig a befolyás teljes hiányát. Meglepó, hogy az egyes kérdésekre a társaságok sokszor teljesen ellentétes válaszokat adtak, ami adódhat a vállalatok sajátos helyzetéból, eltérô vállalati kultúrájából, de magyarázhatja egyszerúen az is, hogy a válaszok teljes egészében a válaszadó szubjektív értékítéletétôl függtek. Négy társaság válaszai alapján az egyéb érintettek sorrendje és befolyásuk átlagos értéke a következő:
1. Állami hatóságok* -
2. Média -
3. Társadalom* -
6. Vevôk (ügyfelek) -
7. Szakszervezetek -
8-10. Beszállítók; bankok; helyi önkormányzat -

1,7

2,5

2,7

4-5. Munkavállalók; könyvvizsgálók -

2,8

3

3,3
Három társaság válasza alapján úgy túnik, hogy a vállalatok társaságirányítási rendszerére az állami hatóságok vannak a legerôsebb befolyással. Ez érthetô, hiszen az iparág múködését erôsen szabályozzák a különféle törvények, és a gyártóknak számos kritériumnak kell megfelelniük. A média elókelő helyezése kevésbé érthetô, de ezzel kapcsolatban azt is meg kell jegyezni, hogy a négyból két vállalat válasza szerint a médiának nagyon erốs a befolyása (1), míg a másik kettô szerint a média egyáltalán nem befolyásolja a vállalat társaságirányítását (4). A harmadik helyen a társadalom áll, ami utalhat a vállalatok társadalmi felelősségvállalására, amelyet mindegyik társaság honlapja és egyéb kiadványa hangsúlyoz. Ugyanakkor a számérték $(2,7)$ inkább közepes, mint erós befolyást jelez. A korábbiakban elmondottak tükrében - miszerint a vállalatoknál nagyon alacsony a fluktuáció, erôs az elkötelezettség, a munkavállalók küldöttei jelen vannak a felügyelóbizottságban, és a legtöbb alkalmazott hoszszú évek óta dolgozik a vállalatnál - meglepó, hogy a munkavállalók csak ilyen kis mértékben befolyásolják a társaságok irányítását.

Szintén érdekes a vevớk helyzete, hiszen azt gondolhatnánk, hogy a gyógyszeripari társaságok nagymértékben függnek a vevơiktől, s ez alapján erôsebb befolyásra számíthatnánk. Azt is meg kell említeni, hogy ebben az esetben is volt olyan vállalat, amely a vevók befolyását nagyon erósnek ítélte. A válaszok azt mutatják, hogy a szakszervezetek, a beszállítók, a bankok és a helyi önkormányzat alig befolyásolják a vállalatok társaságirányítását. Ezek alapján úgy túnik, hogy a beszállítók alárendelt pozícióban vannak a gyógyszergyárakkal szemben. A bankok gyenge befolyása arra utalhat, hogy a vállalatok többnyire más forrásokból teremtik elô a szükséges tôkét, és nem szorulnak rá a banki segítségre. Érdemes megemlíteni, hogy a bankok gyenge befolyása a német gyakorlat ellentéte. Az egyes kategóriák számértékei általánosságban azt mutatják, hogy az egyéb érintettek befolyása nem jelentős, hiszen az állami hatóságokon és a médián kívül minden kategória értéke közelebb van a négyhez, mint az egyhez.

A négy vállalatból háromban múködik vállalati tanács. Ezekre a testületekre többnyire az jellemzó, hogy figyelembe veszik a vállalat általános érdekeit, hogy a vállalaton belüli társadalmi béke megórzésének fontos intézményei, és hogy a testület tagjai általában elfogulatlanok és együttmúködôk. Az egyik társaság szakszervezettel is kötött megállapodást, és az együttmúködésüket nagyon nyíltnak és eredményesnek ítéli meg. Ettól függetlenül a szakszervezet nincsen erôs befolyással a vállalat múködésére. 
A vállalatok és a különböző hitelnyújtók közti kapcsolat is többnyire jelentéktelen. A társaságok a különbözố hitelnyújtók közül a kereskedelmi és a befektetési bankokkal állnak kapcsolatban, de ez a kapcsolat is gyengének mondható.

\section{Az eredmények összefoglalása}

$\mathrm{Az}$ alábbiakban a kérdő́ivek és egyéb információk alapján összefoglalom a magyarországi gyógyszeripari társaságok kormányzási gyakorlatának jellemzőit. Emellett megnevezem azokat a tényezóket, amelyek a felmérés tapasztalatai alapján - véleményem szerint - nagymértékben befolyásolják a vállalatok társaságirányítási módszereit és megoldásait. A jellemzốk öszszegyújtése során természetesen törekedtem arra, hogy csak olyan megállapításokat tegyek, amelyek érvényességében bizonyos vagyok, de a felmérésben rész vevố vállalatok kis száma és a válaszok egy részének magas fokú szubjektivitása miatt előfordulhat, hogy egyes megállapítások a magyar gyógyszeripar egészét tekintve helytelennek bizonyulnak.

A magyar gyógyszeripar vállalati kormányzási rendszerére tehát az alábbiak jellemzók:

- A magyar gyógyszeripar vállalatai túlnyomó többségben zárt formában múködnek. A legjellemzóbb társasági forma a korlátolt felelósségú társaság, de találhatunk zártkörúen múködő részvénytársaságokat is a vállalatok közt. A Budapesti Értéktőzsdén csupán három - humángyógyszer-gyártással foglalkozó - gyógyszeripari társaság van jelen. Mindezek megfelelnek a társasági formák egész országra jellemző arányainak, és a magyar tókepiac általános fejletlenségének is.

- A gyógyszeripari vállalatok tulajdonosi szerkezete alapvetôen megegyezik a hazai társaságok általános jellemzóivel. A legtöbb vállalat külföldi anyacég leányvállalataként múködik, de a privatizáció következtében a korábban magyar állami tulajdonban lévő gyógyszergyárak tulajdonosi szerkezetében is a külföldi befektetốk dominálnak. Ezek túlnyomó többsége szakmai befektető, aminek következtében a nagy magyar gyógyszergyárak egy része is ma már leányvállalatként múködik. Szintén megfelel az általános magyar jellemzóknek, hogy a gyógyszeripari cégek tulajdonosi szerkezete erősen koncentrált, a külföldi szakmai befektetô tulajdoni hányada nemegyszer 100\%-hoz közeli. A tulajdonosi koncentráció a tőzsdei vállalatok esetében is tapasztalható, de jóval kisebb mértékú. Az állam tulajdonosi szerepe - szemben néhány más iparággal - a gyógyszeriparban már nem meghatározó, a legtöbb társaság tulajdonosai közt egyáltalán nincs jelen az állam. A magánbefek- tetôk szerepe a gyógyszeriparban is csekély, de a dolgozói és vezetối tulajdon mértéke is alacsony.

- A német kormányzási rendszerrel ellentétben Magyarországon a gyógyszeripari vállalatok tulajdonosai közt sincsen meghatározó szerepe a bankoknak. Ugyanakkor a szektor érdekessége, hogy a bankok hitelezói szerepe is csekély, ami arra utal, hogy a gyógyszeripari vállalatok nem szorulnak rá a külsố finanszírozásra. Ennek megfelelően a bankok képviselői jellemzően nincsenek jelen a társaságok vezetô testületeiben, a pénzintézetek befolyása a vállalatok társaságirányítására jelentéktelen, és a kapcsolat is inkább gyengének mondható a vállalatok és a hitelintézetek között.

- A vállalatok múködtetésében, stratégiájában a hoszszú távú szempontok érvényesülnek, ami leginkább a tulajdonosi struktúrával magyarázható.

- Az egyéb érintettek (társadalom, munkavállalók, vevók stb.) iránti felelôsség hangsúlyozása a legtöbb vállalat kiadványaiban, honlapján megjelenik. Ez jelentheti azt, hogy a gyógyszeripari társaságok gyakorlata a stakeholder modellhez és a német kormányzási rendszerhez áll közelebb ebból a szempontból. Ugyanakkor a magyarázat lehet egyszerúen egy divathullám is, ami más iparágak vállalataira is jellemző. Tény, hogy a nagyobb gyógyszeripari társaságok számos rendezvényt, alapítványt, kezdeményezést támogatnak anyagilag, ugyanakkor a kérdőívekból az derül ki, hogy az egyéb érintettek befolyása a vállalatok társaságirányítási rendszerére inkább közepes vagy gyenge.

- A gyógyszeripari társaságokra - ugyanúgy, mint általában a hazai vállalatokra - az jellemző, hogy az igazgatóság szerepe meghatározóbb, mint a felügyelő́bizottságé. Ugyanakkor a kérdőívekből az is látszik, hogy a vállalatok irányítását leginkább a felsố vezetés végzi.

- A válaszok azt mutatják, hogy a nók a társaságirányításban jelentősen kevesebb szerephez jutnak, mint a férfiak. Az túnik valószínúbbnek, hogy ez nem iparági sajátosság, hanem a magyarországi vállalatokra általában igaz, de természetesen a felmérés ezt nem igazolhatja.

- A gyógyszeripari cégekre a hierarchia minden szintjén nagyon alacsony fluktuáció jellemző. A felsô vezetés tagjait többnyire a vállalaton belülról választják. A vezető tisztségviselôk (vezérigazgató, igazgatóság elnöke, felügyelőbizottság elnöke) jellemzóen hoszszú ideig töltik be posztjukat.

- A gyógyszeripari társaságokra nem jellemzó az elnöki és a vezérigazgatói pozíció összekapcsolása, de a vezérigazgató általában az igazgatóság szavazattal rendelkező tagja. 
- Az igazgatóságok tagjainak többsége külső, nem végrehajtó igazgató. Ez a gyakorlat, és egyéb kérdésekre adott válaszok azt mutatják, hogy a vizsgált társaságokban az igazgatóság inkább a menedzsment munkájának ellenórzését látja el, semmint a klasszikus értelemben vett ügyvezetối feladatokat. A nagyobb vállalatok esetében úgy túnik, hogy az igazgatóságoknak nincs komoly hatalma a vállalat múködtetése felett, azt inkább a vállalat menedzsmentje végzi. Ezzel szemben a kisebb társaságoknál az igazgatóság szerepe meghatározóbb, de a testület elsôdleges feladata ezekben az esetekben is a felsôvezetés ellenórzése.

- A vizsgált vállalatoknál a felügyelóbizottság elsődleges feladata a menedzsment ellenőrzése. A válaszok alapján úgy túnik, hogy az FB szerepe nem jelentôs. Az igazgatóságról és az FB-ról elmondottak alapján felmerülhet a kérdés, hogy szükség van-e felügyelőbizottságra, hiszen az ellenőrzési feladatokat részben most is az igazgatóság végzi. Elképzelhetô, hogy a jogalkotó ezt ismerte föl, és részben ennek köszönhető, hogy az új (2006-os) Gt. már lehetôvé teszi a nyilvánosan múködő részvénytársaságok számára, hogy egyszintú társaságirányítási rendszerrel múködjenek. Az új törvény a zártkörúen múködố részvénytársaságok számára is csak abban az esetben teszi kötelezővé az FB létrehozását, ha a foglalkoztatottak száma meghaladja a 200 fốt.

- A többségi tulajdonos befolyása nem teljesen egyértelmú. Az tény, hogy koncentrált tulajdonosi szerkezet esetén a többségi tulajdonos valamilyen formában képviseltetve van a vállalatok társaságirányításában. Ugyanakkor ennek módja és mértéke változatos. A befolyás abban az esetben a legerősebb, amikor a tulajdonos a menedzsmentben képviselteti magát. Azonban van olyan nagyvállalat, amelynek külföldi szakmai befektetôje ezt nem teszi meg. Az igazgatóságban többségben lévő képviselốk ezt ellensúlyozhatnák, azonban a válaszok szerint a testület nem rendelkezik jelentős hatalommal. Ez megkérdőjelezi a nagyszámú tulajdonosi küldött delegálásának hasznát is.

- Több testületben (igazgatóságban és felügyelóbizottságban) is helyet kap gazdasági jogász és egyetemi oktató. A felügyelóbizottságok munkavállalói küldöttei jellemzóen a vállalatok szellemi dolgozói. Az egyéb érintettek képviselối többnyire nincsenek jelen a testületekben.

- A gyógyszeripari társaságoknál nem jellemző a részvényopciókkal történó javadalmazás. A testületek tagjai többnyire éves fix díjban részesülnek.

- A gyógyszeripari vállalatok társaságirányítására többnyire nem jellemzô a korszerú kormányzási módszerek alkalmazása. Ennek megfelelően a testületekben többnyire nem múködnek állandó bizottságok, nincsenek a múködésre vonatkozó írott szabályok, és nem jellemzô a testületi üléseken kívüli döntéshozatal.

A kérdő́ivek alapján megpróbáltam nemcsak a jellemzóket, hanem az ok-okozati kapcsolatokat is felkutatni. Véleményem szerint ugyanis az az igazán izgalmas kérdés, hogy melyek azok a tényezôk, amelyek jelentősen befolyásolják egy vállalat kormányzási gyakorlatát. Az általam vizsgált vállalatok mindegyike a magyar jogi keretek között, a gyógyszeriparban, részvénytársasági formában múködik. A szektor társaságirányítási módszerekre gyakorolt hatását igazán csak akkor lehetne megállapítani, ha számos iparágból rendelkeznénk mintával, amelyeket egymással össze tudnánk hasonlítani. A vizsgált vállalatok gyakorlata között tapasztalt különbségeket véleményem szerint a leginkább a következő tényezók magyarázzák:

- A vállalati kormányzás gyakorlatát jelentősen befolyásolja, hogy a vállalat zártkörúen, vagy nyilvánosan múködő részvénytársaság. A különbségek alapvetôen az eltérô szabályozásnak köszönhetôek. A nyilvánosan múködố részvénytársaságokra részben más (többnyire szigorúbb) törvényi szabályok vonatkoznak, s emellett most már a BÉT Felelős Vállalatirányítási Ajánlásait is szem előtt kell tartaniuk. De ez a különbség a szabályozottságon kívül kihathat a vállalat tulajdonosi struktúrájára is.

- Az egyik legfontosabb befolyásoló tényezô a társaságok tulajdonosi szerkezete. A vezetó testületek összetétele alapvetően függ attól, hogy a társaság tulajdonosi szerkezete koncentrált vagy szórt, hogy van-e domináns külföldi tulajdonosa a vállalatnak, s hogy a vállalat szakmai vagy pénzügyi befektetók kezében van.

- A társaság múködésének eredményessége is befolyásolhatja kormányzási gyakorlatát. A csőd közeli állapot, az állandó likviditási problémák kihathatnak a vállalat társaságirányítási módszereire is. Mindezek befolyásolhatják a vezetô testületek összetételét, szerepét, múködését, sốt még a testületi tagok javadalmazási rendszerét is.

- A vállalatok méretének hatása nem egyértelmú. Vannak olyan területek, amelyekre valószínúleg a vállalati méret nincs jelentős hatással. Ilyen például a menedzsment létszáma. A vezetô testületek (igazgatóság, felügyelóbizottság) létszámát tekintve a kérdőívek alapján nem lehet biztosat mondani. Ugyanakkor a felmérés alapján úgy túnik, hogy a vezetó testületek a kisebb méretú vállalatok múködtetésé- 
ben fontosabb szerepet töltenek be. Ez a megállapítás azonban szubjektív válaszokon alapul. A vállalati méret társaságirányításra gyakorolt hatása a felmérés alapján tehát nem igazolható.

- A vállalati profil (Rx- vagy OTC-termékek) közvetlenül nem befolyásolja a kormányzási gyakorlatot. Azonban jelentốs hatással van a vállalat méretére, így közvetve a társaságirányítást is befolyásolhatja, de ezt - ahogy azt fentebb is említettem - a felmérés nem igazolja.

\section{Összegzés}

Dolgozatomban a magyarországi gyógyszeripari cégek vállalati kormányzási gyakorlatát vizsgáltam egy németországi kérdôív segítségével végzett felmérés alapján. A felmérés a vállalatok tulajdonosi szerkezetét, a menedzsment és a vezetô testületek (igazgatóság és felügyelőbizottság) összetételét, múködését, szerepét és a társaság múködtetésére gyakorolt hatását vizsgálta. Emellett a kérdőív egy külön fejezetben kitért a vállalati múködés egyéb érintettjeinek befolyására is. A felmérés eredményeinek összegzéseként összegyújtöttem azokat a jellemzóket, amelyek a kapott válaszok tanúsága szerint általában igazak a magyarországi gyógyszeripari társaságok kormányzási gyakorlatára. Azonban a bemutatott eredmények vizsgálatakor szem elôtt kell tartani néhány olyan tényezôt, amelyek miatt azok eltérhetnek a valóságtól. A legfontosabb ezek közül, hogy a felmérés csupán hat vállalatra terjedt ki, és számos kérdésre csak négy társaságtól érkezett válasz. Az is torzíthatja az eredményeket, hogy a kérdôív egyes kérdéscsoportjaira érkezô válaszok teljes egészében a válaszadó szubjektív értékítéletétôl függtek. Az sem elhanyagolható, hogy a kérdőíveket egyes esetekben olyan vállalati munkatársak töltötték ki, akik - munkakörükból adódóan - nem ismerik pontosan a vezető testületek munkáját. Kérdéses tehát, hogy a - fóleg a szubjektív kérdésekre érkezett - válaszok mennyiben felelnek meg a valóságnak. A kérdőív értelmezését nehezítette az is, hogy - a kérdőív németországi eredete miatt - egyes kérdések a magyar rendszerrel nincsenek összhangban. Az is fontos szempont, hogy a kutatás - elsősorban a kérdő́iv fókusza miatt - kizárólag részvénytársasági formában múködő vállalatokra terjedt ki, holott a magyar gazdaságra - darabszámát tekintve - általában jellemzô a korlátolt felelôsségú társaságok túlsúlya.

Mindezeket szem előtt tartva mégis úgy gondolom, hogy a megállapítások többnyire érvényesek, és minden bizonnyal nincsen köztük olyan, amely szöges ellentétben állna a valósággal. Ezzel együtt úgy vélem, hogy a vállalati kormányzás témakörében további vizsgálódások indokoltak. A nemzetközi összehasonlíthatóság érdekében érdemes az általam is használt kérdôív segítségével további felméréseket készíteni a magyar gazdaság más iparágaiban. Természetesen a különbözó iparágakkal kapcsolatos eredmények összehasonlításával és összegzésével egyrészt választ kaphatunk arra, hogy az iparági sajátosságok mennyiben befolyásolják a társaságok kormányzási gyakorlatát, másrészt meghatározhatjuk a magyar társaságirányítási gyakorlat általános jellemzőit. Célszerú lenne ezeket a felméréseket interjú formájában lebonyolítani a kérdésekkel kapcsolatos félreértések elkerülése érdekében. Az információk értékét tovább növelné, ha az egyes kérdéscsoportokra olyan személyek válaszolnának, akik pontosan ismerik az adott terület múködését, összefüggéseit (pl. az igazgatósággal kapcsolatos kérdésekre igazgatósági tagnak kellene válaszolnia). Ez azonban természetesen nagyon nehezen megoldható feladat, hiszen a kérdésekból adódóan a vállalati hierarchia csúcsán lévő munkatársakkal kellene interjút készíteni, ami az esetek döntő többségében igen nehezen, vagy egyáltalán nem megvalósítható.

Emellett úgy gondolom, hogy a késóbbiekben érdemes lenne egy olyan kérdőívet is összeállítani, amely jobban illeszkedik a magyar sajátosságokhoz. Véleményem szerint ez nem feltétlenül jelenti a nemzetközi összehasonlíthatóság hiányát, ugyanakkor a magyar gyakorlatot talán jobban meg lehetne ismerni ennek segítségével.

Mivel a magyar gazdaságban a kft.-k jóval nagyobb számban találhatók meg, mint az rt.-k, ezért megfontolandó a vizsgálat kiterjesztése a korlátolt felelôsségú társaságokra is. Természetesen ebben az esetben az eltérô szabályozás miatt változtatás nélkül semmiképp sem alkalmazható az általam felhasznált kérdốiv, hiszen egy kft.-nél nem feltétlenül múködnek olyan vezetô testületek, amelyekre a kérdôív rákérdez. A tulajdonosi struktúra, a csoportos döntés és vezetés, a felelősség megosztása, a különböző érintettek befolyása azonban ennél a társasági formánál is vizsgálható.

$\mathrm{Az}$ is érdekes kérdés lehet a kutatók számára, hogy a Budapesti Értéktőzsde által megfogalmazott Felelós Vállalatirányítási Ajánlások milyen módon hatnak az egyes vállalatok kormányzási rendszerére, módszereire. Ez a kérdés elsősorban a tôzsdén jelenlévő vállalatok esetében releváns.

Ugyancsak izgalmas kérdés, hogy az új (2006-os) Gt. következtében mennyire fog megváltozni a magyar kormányzási gyakorlat. Az új szabályozás számos újítást tartalmaz, és több korszerú társaságirányítási megoldással is foglalkozik (pl. auditbizottság, testületi ülé- 
sek elektronikus hírközlő eszközök igénybevételével való lebonyolítása). Emellett egyes rendelkezései az angolszász, míg mások a német társaságirányítási modellhez való közeledést teszik lehetôvé. Kérdéses tehát, hogy hosszú távon a magyar gyakorlat jellegzetességei alapján marad-e a két domináns modell között, vagy jelentősen elmozdul az egyik irányba. Talán a legérdekesebb változás az lenne, ha a magyar gyakorlat, amely hagyományosan a német rendszerhez áll közelebb, az angolszász modellhez közeledne. A szabályozásokban bekövetkezô változások alapján ez a lehetőség is elképzelhetô.

\section{Lábjegyzet}

${ }^{1}$ A definíciók sokszínúségérôl lásd: Angyal Ádám (2001): Vállalati kormányzás - Corporate governance. Aula, Budapest; vagy Siklósi Árpád (2006): A vállalati kormányzás gyakorlata a magyarországi gyógyszeripari társaságoknál. Szakdolgozat, Budapesti Corvinus Egyetem, Gazdálkodástudományi Kar, Vezetéstudományi Intézet.

2 IMS Health Hungary (2006): Pharmaceutical Market Overview - 2005 Year End Report - Hungary.

${ }^{3}$ http://www.sanofi-aventis.hu - sanofi-aventis Magyarország, Chinoin Rt.

${ }^{4}$ http://www.teva.hu - TEVA Magyarország Rt., TEVA Gyógyszergyár Rt.

5 MTI (2005): A Valeant Pharmaceuticals eladta magyarországi vállalkozását. OTS-hírek, 2005. augusztus 10. http://ots.mti.hu/ news.asp?newsid=32486, 2006. április 25.

${ }^{6}$ IMS Health Hungary (2006): Pharmaceutical Market Overview - 2005 Year End Report - Hungary.

${ }^{7}$ http://www.magyosz.org - Magyarországi Gyógyszergyártók Országos Szövetsége

8 2007-tôl változott az OTC-termékek köre. Az új szabályozás az Algopyrint a vényköteles gyógyszerek közé sorolja.

9 IMS Health Hungary (2006): Pharmaceutical Market Overview - 2005 Year End Report - Hungary.

${ }^{10}$ IMS Health Hungary (2006): Pharmaceutical Market Overview - 2005 Year End Report - Hungary.

${ }^{11}$ Figyelô TOP 200 (2005): A legnagyobb magyarországi vállalkozások a számok tükrében. Sanoma, Budapest.

12 Angyal Ádám és Csanda Júlia 2005. július 1. és augusztus 31. között a magyar banki és biztosítási szektorban végeztek felmérést az általuk módosított kérdőív segítségével. A magyarországi vállalatok kormányzási gyakorlatára vonatkozóan ennek a kérdőívnek a segítségével eddig ez az egy felmérés - és annak elemzése - készült el. Lásd: Angyal Ádám - Csanda Júlia (2005): A banki, biztosítási szektor vállalatirányítási jellemzói - Egy kérdőíves felmérés tapasztalatai. Kézirat, Budapest, 2005. december 5. (Ez a Vezetéstudományban is megjelent, lásd www. bsm.hu publications web oldalon.)

13 Voszka Éva (2000): Hatásköri játékok - Miról dönthet a vezérigazgató? Cégvezetés, VIII/9. 151-158. old.

${ }^{14}$ Az originális gyógyszerek a gyártó által kifejlesztett, új hatóanyagot tartalmaznak. A magas fejlesztési költségek miatt az originális termékek bizonyos ideig szabadalmi védettséget élveznek, ami idő alatt az adott gyógyszert csak kifejlesztôje állíthatja elő.
Ezzel szemben a generikus gyógyszerek olyan készítmények, „amelyeknek szabadalmi védettsége lejárt, ezért azokat bárki előállíthatja, forgalmazhatja" - Dr. Boruzs Hedvig (1999): Generikus gyógyszerek törzskönyvezése Magyarországon az iparjogvédelem szemszögéből. Iparjogvédelmi és Szerzői Jogi Szemle, CIV/4. http://www.hpo.hu/kiadv/ipsz/199908/boruzs. html, 2006. április 24.

15 A tulajdonosi szerkezetekre vonatkozó megállapítások - ahogy a kutatás egyéb eredményei is - a 2006. áprilisi állapotokat tükrözik.

${ }^{16}$ Dr. Csucska Elek fedezte fel a társaság által forgalmazott gyógyhatású készítmények alapanyagát, a humifulvátot.

${ }_{17}$ A továbbiakban az elemzés csak öt vállalat - Richter, Egis, Chinoin, Béres, HUMET - adataira épül.

18 Angyal Ádám - Csanda Júlia (2005): A banki, biztosítási szektor vállalatirányítási jellemzói - Egy kérdőíves felmérés tapasztalatai. Kézirat, Budapest, 2005. december 5. 8. old.

19 A felmérés készítésekor még az 1997-es Gt. volt hatályban, ezért a dolgozat hivatkozásai erre vonatkoznak.

\section{Felhasznált irodalom}

1997. évi CXLIV. törvény a gazdasági társaságokról

2006. évi IV. törvény a gazdasági társaságokról

Angyal Ádám - Csanda Júlia (2005): A banki, biztosítási szektor vállalatirányítási jellemzői - Egy kérdôíves felmérés tapasztalatai. Kézirat, Budapest, 2005. december 5.

Angyal Ádám (1997): Vállalatok kormányzása. Vezetéstudomány, XXVIII/12. 26-41. old.

Angyal Ádám (1998): A vállalati kormányzás gyakorlata. Vezetéstudomány, XXIX/10. 1-17. old.

Angyal Ádám (1999): A kormányzás múvészete - Globális vállalatok vezetése. Cégvezetés, VII/6. 151-159. old.

Angyal Ádám (2001): Vállalati kormányzás - Corporate governance. Aula, Budapest

Angyal Ádám (2002): A kormányzás mikroszintje. CEO Magazin: Magazin cégvezetốknek, üzletembereknek, III/1. 7-9. old.

Angyal Ádám (2003): A vezetés mesterfogásai. Kossuth Kiadó, Budapest

Bakacsi Gyula (2002): Szervezeti magatartás és vezetés. KJK-Kerszöv, Budapest

Bartók István (2001): Vállalatkormányzás. Ph.D. értekezés. Budapesti Közgazdaságtudományi és Államigazgatási Egyetem, Vállalatgazdaságtan Tanszék, Budapest

Berlin Initiative Group (2000): German Code of Corporate Governance. http://www.gccg.de/eng_German-Codeof-Corporate-Governance.pdf, 2006. március 12.

Bógel György - Salamonné Huszty Anna (1998): Vállalatvezetés felsőfokon. Kossuth Kiadó, Budapest

Budapesti Értéktózsde Részvénytársaság (2004): Felelős Vállalatirányítási Ajánlások. Budapest. http://www.bet. hu/file/BET-CGvegHU-040123.pdf, 2006. január 24.

Cadbury, A. et. al. (1995): Report of the Committee on the Financial Aspects of Corporate Governance. GEE, London.

Chikán Attila (2001): Vállalatgazdaságtan. Második kiadás. Aula, Budapest 
Dankó Dávid (2003): A költségmenedzsment lehetőségei a gyógyszeriparban. Szakdolgozat. BKÁE Vezetési és Szervezési Tanszék, Budapest

Dobák Miklós - Steger, T. (2003): Corporate Governance in Central and Eastern Europe - An introductory review. Journal for East European Management Studies, VIII/3. pp. 223-235.

Dobák Miklós (2002): Szervezeti formák és vezetés. KJKKerszöv, Budapest

Dr. Boruzs Hedvig (1999): Generikus gyógyszerek törzskönyvezése Magyarországon az iparjogvédelem szemszögéből. Iparjogvédelmi és Szerzői Jogi Szemle, CIV/4. http://www.hpo.hu/kiadv/ipsz/199908/boruzs. html, 2006. április 24.

Editorial (2000): Corporate Governance - the subject, whose time has come. Corporate Governance, VIII/4. pp. 289-296.

Figyelő TOP 200 (2005): A legnagyobb magyarországi vállalkozások a számok tükrében. Sanoma, Budapest

Gregory, H.J. - Simmelkjaer, R. T. (ed) (2002): Comparative Study Of Corporate Governance Codes Relevant to the European Union And Its Member States. European Commission. http://www.odce.ie/_fileupload/services/ EU\%20Comparison.pdf, 2006. március 11.

Gulácsi Gábor (2004): „Felelős vállalatirányítást” Magyarországon? Egy vállalatirányítási probléma gyakorlati nézőpontból. In: Czakó Erzsébet - Dobos Imre - Kőhegyi Anita (szerk.) (2004): Vállalati versenyképesség, logisztika, készletek: Tanulmányok Chikán Attila tiszteletére. BKÁE Vállalatgazdaságtan Tanszék, Budapest.

Hessel, M. (1995): Igazgatótanácsok: ellenórzés képviselet útján. In: Hessel, M. (ed.): Jó igazgatókat keresünk. Közgazdasági és Jogi Könyvkiadó, Budapest

Hitt, M.A. - Ireland, R.D. - Hoskisson, R.E. (2005): Strategic Management: Competitiveness and Globalization (Concepts). 6th Edition. Thomson, South-Western, USA

IMS Health Hungary (2006): Pharmaceutical Market Overview - 2005 Year End Report - Hungary.

Keasey, K. - Thompson, S. - Wright, M. (ed.) (1999): Corporate Governance. Elgar, Cheltenham (etc.).

Lauter, G. P. - Rehman, S. S. (2003): A vállalati kormányzás fejlődése az Európai Unióban. Európa Fórum, XIII/3-4. 140-157. old.

Lorsch, J.W. (1995): Empowering the Board. Harvard Business Review, LXXIII/1. pp. 107-117.

Mathiesen, H. (2002): The Encyclopedia about Corporate Governance. http://www.encycogov.com/ WhatIsGorpGov.asp, 2006. március 11.

Mayer, C. (1995): Vállalatirányítás a piac- és az átmeneti gazdaságokban. In: Hessel, M. (ed.): Jó igazgatókat keresünk. Közgazdasági és Jogi Könyvkiadó, Budapest
Millstein, I.M. - Albert, M. - Cadbury, A. - Denham, R E. Feddersen, D. - Tateisi, N. (1998): Corporate governance: Improving competitiveness and access to capital in global markets - A Report to the OECD by the Business Sector Advisory Group on Corporate Governance. OECD, Paris Mintzberg, H. (1983): Power in and around organizations. Prentice-Hall, Englewood Cliffs.

Mohai György (2003): Felelős vállalatirányítás - divat vagy a piacok megmentôje? BÉT Elemzések, 2003. november 25. Budapesti Értéktôzsde Részvénytársaság. http://www. bse.hu/file/Felelos_vallalatiranyitas.pdf, 2006. március 11 .

Monks, R.A.G. - Minow, N. (2004): Corporate Governance. Third Edition. Blackwell Publishing, Malden (etc.)

OECD Principles of Corporate Governance (2004). OECD, Paris. http://www.oecd.org/dataoecd/32/18/31557724. pdf, 2006. március 11.

Pound, J. (1995): The Promise of the Governed Corporation. Harvard Business Review, LXXIII/2. pp. 89-98.

Roe, M.J. (1996): Strong Managers - Weak Owners: The Political Roots of American Corporate Finance. Second Edition. Princeton University Press, Princeton

Salmon, W.J. (1993): Crisis Prevention: How to Gear Up Your Board. Harvard Business Review, LXXI/1. pp. 68-75.

Sárközy Tamás (2001): Magyar Gazdasági Jog I. Gazdasági státusjog. Harmadik kiadás. Aula, Budapest

Sárközy Tamás (2005): Az új társasági törvény társaságok vezetési rendszerérôl szóló rendelkezéseiről. Gazdaság és Jog, XIII/5. 8-11. old.

Tricker, R. (ed.) (1993): Corporate Governance. International Review, XI/1.

Voszka Éva (2000): Hatásköri játékok - Miról dönthet a vezérigazgató? Cégvezetés, VIII/9. 151-158. old.

Witt, P. (2004): The Competition of International Corporate Governance Systems - A German Perspective. Management International Review, ILIV/3. pp. 309-333.

Honlapok:

http://www.beres.hu - Béres Gyógyszergyár Rt.

http://www.bet.hu - Budapesti Értéktőzsde

http://www.egis.hu - Egis Gyógyszergyár Rt.

http://www.humet.hu - Humet Rt.

http://www.magyosz.org-Magyarországi Gyógyszergyártók Országos Szövetsége

http://www.richter.hu - Richter Gedeon Rt.

http://www.sanofi-aventis.hu - sanofi-aventis Magyarország, Chinoin Rt.

http://www.teva.hu - TEVA Magyarország Rt., TEVA Gyógyszergyár Rt.

Cikk beérkezett: 2006. 11. hó

Lektori vélemény alapján átdolgozva: 2007. 4. hó 